D A V I D W. W I L C OX

Board of Governors of the Federal Reserve System

\title{
Reforming the Defined-Benefit Pension System
}

IN SOME RESPECTS THE defined-benefit (DB) pension system in the United States is remarkably successful. In 2001 (the latest year for which data from Form 5500 filings are available), roughly $\$ 130$ billion was paid in benefits to 11 million recipients. DB plans in the aggregate held an estimated $\$ 1.8$ trillion in assets as security against future benefit payments, and in so doing made a large pool of capital available for efficient deployment through financial markets. ${ }^{1}$ Over the thirty-plus years since the founding of the Pension Benefit Guaranty Corporation (PBGC), the government corporation that insures private sector DB plans, more than 168,000 plans have been terminated, but only in about 3,500 of those cases has the PBGC had to step in as trustee; in the other roughly 165,000 cases, plans had sufficient assets on hand to meet accrued obligations. ${ }^{2}$ Even the often-cited $\$ 23$ billion negative net position on the PBGC's balance sheet must be viewed in context, as it represents only a small fraction of total benefits paid since the founding of the insurance program in 1974.

In many respects, however, the system is not working as well as it should. One problem is that the system exposes some workers-those whose

I am grateful to Zvi Bodie, Jeremy Bulow, Jeffrey Brown, Edward DeMarco, Douglas Elliott, Mark Iwry, Wendy Kiska, Nellie Liang, Deborah Lucas, Stephen Oliner, George Pennacchi, Marvin Phaup, Paul Smith, and Jonathan Wright for helpful conversations and comments on earlier drafts. Several of these individuals have been extraordinarily generous with their time. I am also grateful to Blake Bailey for excellent research assistance. The views expressed here are those of the author and are not necessarily shared by the Board of Governors of the Federal Reserve System or the other members of its staff.

1. U.S. Department of Labor (2006).

2. PBGC (2005h, table S-3). 
benefits exceed the maximum amount guaranteed by the government insurer - to a form of financial risk that they likely are ill positioned to bear and that they may not fully understand. In part the unsuitability of this risk reflects the fact that pensions loom large relative to many workers' financial portfolios. It also reflects the fact that a risky pension generally exposes workers to own-firm risk. (The own-firm nature of the risk inherent in a lessthan-fully-secure DB plan arises because one of the preconditions of plan termination is that the sponsor must be in bankruptcy proceedings.) For some workers the downside of this risk has been realized: they have suffered severe blows to their personal financial situation when their employers have terminated their DB plans with assets grossly insufficient to pay accrued benefits, and the PBGC covered only a portion of their loss.

A second problem with the current system is that mispriced PBGC insurance coverage encourages excessive risk taking on the part of both workers and firms. Julia Coronado and Nellie Liang find that "even after controlling for cash availability ... firms closer to bankruptcy have funded their plans much less generously."”3 Anecdotally, other observers have cited cases in which firms in shaky financial condition have granted benefit increases in lieu of wage or salary increases, on the theory that if the fortunes of the firm improved, the firm would be able to meet the newly granted pension obligations, and if not, the government insurance program would step in to fill the gap.

A third problem is that investors seem to have considerable difficulty processing DB-related information accurately. For example, Coronado and Steven Sharpe document that investors seem to be much more sensitive to the smoothed information about pension items currently provided in the body of firms' financial statements than they are to the market-value-based estimates provided in the footnotes. ${ }^{4}$ Similarly, Francesco Franzoni and José Marín show that firms with severely underfunded pension plans-a publicly observable condition - tend to underperform the stock market. ${ }^{5}$ This misvaluation is a matter of macroeconomic concern because it raises the possibility that capital is being misallocated across firms.

A fourth problem with the current system is that it puts taxpayers at risk of providing substantial yet opaque subsidies to the sponsors and partici-

3. Coronado and Liang (2005, p. 2).

4. Coronado and Sharpe (2003).

5. Franzoni and Marín (2006). 
Figure 1. Determination of the Maximum Deductible Contribution

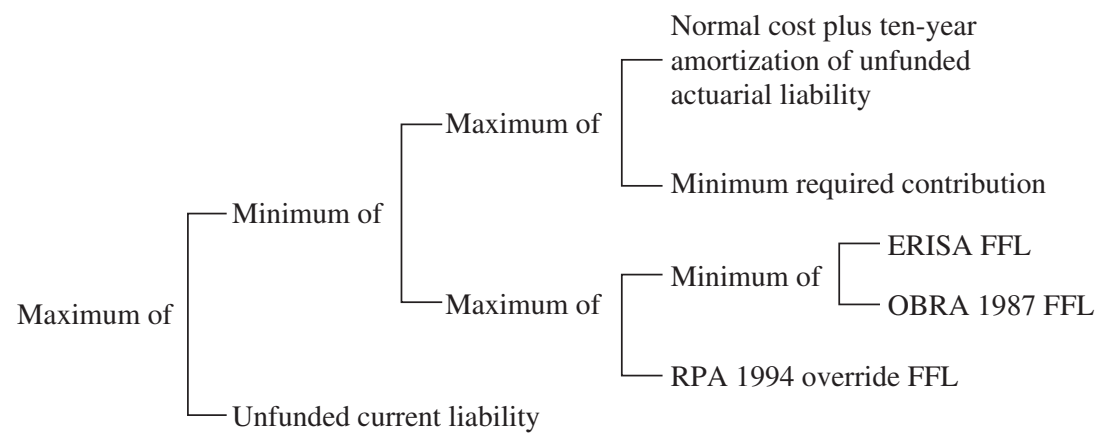

Source: PBGC.

Note: OBRA 1987, Omnibus Budget Reconciliation Act of 1987; RPA 1994, Retirement Protection Act of 1994.

pants of DB plans, beyond the $\$ 23$ billion already reflected on the balance sheet of the federal insurer. In particular, the Congressional Budget Office (CBO) estimates that the insurance provided by the PBGC will be underpriced by $\$ 63$ billion over the next ten years if current law is left in place. ${ }^{6}$ This commitment of resources would come just as other demands on the federal government associated with the retirement of the baby-boom generation are mounting.

A fifth problem is that healthy sponsors confront a real risk that costs will be shifted to them from weaker sponsors. Such a shift would occur if, in an effort to recoup the economic losses already incurred or still in prospect, policymakers were to raise PBGC premiums (which, by construction, are paid only by surviving sponsors) above their economically fair level. A move in this direction would give surviving sponsors an added incentive to bring their plans up to fully funded status and then terminate them, and could therefore deplete the ranks of DB plan sponsors, not because of any inherent flaw in the system or lack of perceived value in DB pensions as a form of compensation, but rather because the costs of sponsorship had been inflated beyond their full and fair level.

One last problem with the status quo is that all sponsors face a regulatory thicket of mind-boggling proportions. One example among many involves the method (which figure 1 attempts to illustrate) that sponsors

6. CBO (2005b). 
must use to determine the maximum contribution they will be allowed to deduct against their income taxes. The basic idea is that sponsors should be allowed to deduct the amount that would be required to boost the plan to fully funded status - but not more, because of the losses to the Treasury that would be associated with such "excess" contributions. As the figure makes evident, however, the basic idea is deeply obscured in the current implementation. Needless complexity in the rules governing DB plans adds cost to the system and therefore discourages sponsorship.

In light of these shortcomings of the current system, this paper puts forward a comprehensive package of reforms with the goal of reviving the existing private DB system. ${ }^{7}$ Given the speed with which that system seems to be shrinking, however, one might well ask, "why bother?" Fundamentally, two reasons argue for undertaking such a program of reform even at this late date: First, even if conventional DB plans are doomed to extinction, considerable time will be required to unwind the plans still in existence, and the advantages of navigating that unwinding under better rules rather than worse ones could be substantial. Second, the demise of the DB system is hardly a foregone conclusion. Although a number of high-profile freezes and terminations have occurred recently, most large sponsors have preserved their plans thus far. Under streamlined rules, a greater number of firms and workers might decide that a DB plan should be retained as part of the overall compensation package.

The shortcomings described above motivate the adoption of three axioms concerning characteristics that an improved pension system should have. ${ }^{8}$ These axioms play a crucial role in the logic of the paper, because the reform proposal that the paper puts forward is derived from them. The first axiom is that workers should be able to view the promise of a DB pension

7. In addition to single-employer plans (plans sponsored by a single firm), the PBGC insures multiemployer plans, which involve, as the name implies, more than one employer and are usually created as part of a collective bargaining agreement. Such plans often cover multiple employers in the same industry within a given geographic region and allow workers to migrate from one employer to another while continuing to accrue benefits in the same plan. (See PBGC, "Multiemployer Insurance Program," www.pbgc.gov/media/key-resources-forthe-press/content/page13544.html.) This paper focuses on the single-employer insurance program because the vast majority of the liability currently recognized by the PBGC arises from that segment of its operations.

8. The Merriam-Webster Online Dictionary defines an axiom as "a statement accepted as true as the basis for argument or inference." 
as free of risk. ${ }^{9}$ This axiom is intended to address the facts that many workers are not well positioned to bear financial risk on the scale posed by an underfunded pension promise and that a risky pension scheme almost always entails meaningful own-firm risk..$^{10}$ If workers understand the nature of that risk, they will offer their employer a lower "price" (in the form of wage and salary concessions) than the capital markets would offer in return for the same cash flow, because, as Lawrence Bader has noted, "employees cannot diversify or hedge this risk in any practical manner," whereas capital markets can do so easily. ${ }^{11}$ Zvi Bodie has referred to the difference between what workers and capital markets would offer in return for pension cash flows as "a wedge of dead-weight loss" that the employer can eliminate by making the DB promise free of risk. ${ }^{12}$ Another realistic possibility is that workers simply do not understand the nature of the risk they are assuming by accepting a less-than-fully-secure DB plan, and so are not fairly compensated for it. ${ }^{13}$

Some analysts have argued that risky DB promises serve an economically and socially useful purpose, in that they give workers a stake in the economic success of their employer. But the objective of aligning the economic interests of workers with those of their firms can be advanced more directly and more transparently using other forms of compensation, such as employee stock ownership plans and long-dated options, which

9. Bodie (2003) argues the same proposition on the basis of much the same logic as is used here. See, for example, the title of his section 3: "Corporate defined benefit promises should be free of default risk."

10. The case for rendering the pension promise risk-free is more compelling, the more highly correlated is human capital with the financial health of the firm, and the less highly correlated is the financial health of the firm with the overall performance of the business sector. If a worker's human capital is perfectly transferable from one firm to another, that worker may suffer little or no direct adverse financial consequences in the event that the employer goes into bankruptcy (leaving aside the issue of the funding status of the DB plan). If a firm's entry into bankruptcy can be predicted perfectly from the performance of the aggregate stock market, then, in a sense, no "own-firm" risk inheres in the pension promise, risky or not.

11. Bader (2004, p. 15).

12. Bodie (2003, p. 66).

13. In the opening sentences of his 1987 article, Ippolito suggests (p. 15) that at least part of the motivation for the Employee Retirement Income Security Act (ERISA) was precisely to reinforce the security of the pension promise: "Congress enacted [ERISA] in 1974 to reduce the long-term risk inherent in private pensions. Advertised as a major piece of workerprotection legislation, it was designed to convert pensions from conditional promises into the equivalent of wages." 
also have the important advantage of not involving the taxpayer as a third-party guarantor. An alternative argument that might be made in favor of a risk-tolerant approach is that, left to their own devices, workers might reasonably choose a risky pension over a safe one in order to gain some exposure to equity risk. But, again, conventional finance theory suggests that a well-informed worker should have little or no appetite for the particular form of risk exposure inherent in an underfunded DB plan, because it involves a heavy dose of own-firm risk even if the pension trust is invested entirely in a well-diversified portfolio. Moreover, to the extent that workers succeed in capturing the value associated with any upside risk in the net worth of the plan, one might expect employers either to trim other forms of compensation or to arrange the assets of the plan so as to reduce or eliminate that upside risk. If pension plans were to be charged an economically fair insurance premium that reflected the market price of all aspects of risk borne by the insurer, and thus the excess value derived at the expense of the PBGC were to be removed, workers' appetites for pension risk would probably be further diminished. And if general equity exposure is the objective, a 401(k) plan is a more appropriate tool.

The second axiom is that taxpayers should be compensated in full at market-consistent rates for the risk that they shoulder in backstopping the federal pension insurance program. As noted above, failure to assess a rational premium motivates sponsors and workers to take on risks they would not otherwise, exposes taxpayers to considerable financial burden at a time of mounting demands on government, and provides a substantial and opaque subsidy. Again, some analysts have argued to the contrarythat the Congress fully intended to set up a system that would transfer resources to firms in distress. But alternative mechanisms (such as unemployment insurance and various forms of worker education and training) are available that might better serve the purpose of cushioning the economic blow inevitably experienced by some workers and firms in a dynamic economy.

The third axiom is that low-risk sponsors should not have to crosssubsidize the insurance coverage provided to their high-risk counterparts. Sponsorship of a DB plan is voluntary, and low-risk sponsors perceiving a threat that costs might be shifted from distressed firms to them could be moved to terminate plans they might otherwise maintain. Genuine insurance can be provided without cross-subsidization. 
Readers who disagree with any of these three axioms, and therefore posit different ones, will reach different conclusions from those derived here.$^{14}$ Equally, readers who find the implications of these three axioms unacceptable must, as a matter of logic, be willing to identify at least one axiom they would be willing to compromise.

In aiming to minimize the risk in the pension promise, the proposed reforms will deliberately build in a degree of redundancy. For example, although one might argue that a sufficiently stringent set of funding requirements would be enough, on its own, to render the pension promise free of risk, this paper recommends that such funding requirements be complemented with market-mimicking insurance premiums and enhanced disclosure to investors and workers. The purpose of this redundancy is to provide multiple layers of protection against failure: If the funding rules do not work exactly as intended, the market-based premiums might still motivate firms to adopt a risk-free stance. And if both of those layers failed, well-informed workers might still encourage firms to provide full security on their pension promises, and well-informed investors might encourage better matching of assets and liabilities once the associated risk is fully appreciated. On the other hand, if an ideal set of funding rules were implemented and succeeded in squeezing pension risk essentially to zero, then a well-designed approach to pricing insurance would likewise squeeze the risk-based component of the premiums essentially to zero, ensuring no unnecessary cost from this element of redundancy. In the end, a sponsor that encountered severe financial difficulty would still be able to cut costs by terminating its pension plan; but if the proposals laid out here worked as intended, the sponsor would leave behind a set of pension promises that could be fulfilled in their entirety, with no loss by workers of benefits already accrued, no cost to the taxpayer, and no shifting of financial responsibility to surviving sponsors.

This paper can be viewed as representing the first step in a wider program. It maps one set of axioms onto their implications, but it obviously does not provide a complete mapping from all possible axioms onto their implications. Nor, more fundamentally, does it derive the axioms from a formal and reasonably realistic model of optimizing behavior on the part of

14. As the discussion below will make clear, the three axioms are taken as conceptual objectives toward which great progress can be made, but not as ends that must be achieved at all cost. 
workers, firms, and taxpayers. ${ }^{15}$ (In this context a reasonably realistic model would be capable of explaining such phenomena as the seeming inability even of equity market participants to accurately infer the implications of information about DB plans for the market value of their sponsors, and the apparent willingness of many workers to increase their exposure to ownfirm risk even beyond that implicit in their investment in firm-specific human capital.) Policymakers must make decisions that reflect the full complexity of the real world, including all the considerations that have been swept aside here. In principle, those considerations could cause policymakers to arrive at quite different conclusions about the appropriate regulatory structure from the ones derived here.

The paper should not be viewed as advocating that workers should be provided risk-free annuities as part of their compensation. Rather, it should be viewed as stipulating that DB pensions should remain as one of the compensation tools available to workers and management as they work out the value-maximizing means of delivering compensation to workers. The paper derives the implications of attaching an important caveat to the use of DB pensions, namely, that if workers are to be promised annuities by their employers, and if taxpayers are to be interposed as third-party guarantors of those annuities, then the pension promise should be essentially free of risk so as to avoid imposing yet more own-firm risk on workers who may already be holding too much of it. In the course of bargaining with their employers, workers should of course be careful not to demand too large a fraction of their overall compensation in the form of such risk-free annuities, taking account of whatever Social Security benefits they might become entitled to. Equity-related compensation and own-firm-riskrelated compensation may be complementary elements of the compensation toolbox, but other vehicles aside from DB plans are available for the purpose of giving workers exposure to those forms of risk. The salient common feature of those other forms of compensation is that they all transparently do not involve the government as guarantor, and they are much more transparent in the manner in which they expose workers to equity risk.

The remainder of the paper is organized as follows: The first section provides a short course in DB plans, with the objective of giving the nonspecialist enough of a toehold on the institutional detail of the system to follow the remainder of the discussion. The next section then briefly pro-

15. This is the objective of research in progress. 
vides a theoretical perspective on three issues of central importance to the regulation of pensions: the concept of liability that sponsors should be required to take as their funding objective; the discount rate that sponsors should use in estimating that liability; and the optimal composition of the portfolio of pension assets. The next section returns from theory to the real world, aiming to summarize what is known from practical experience about the real sources of vulnerability in the current system. In particular, this section attempts to identify the features of current law that have been most instrumental in allowing risk to persist for workers, taxpayers, and healthy sponsors. The objective of this section is to ensure that the reform proposals put forward in this paper actually address and would resolve the fundamental problems currently afflicting DB plans. The next section puts forward the proposed reform program, touching on funding requirements, portfolio investment restrictions, insurance premium pricing, and transparency. This is a case where the details matter, because if the reforms outlined here are to be credible, they must engage with the DB system as it currently exists. Accordingly, the section goes into substantially greater depth, as needed, about the design of the current system. The penultimate section looks many years down the road. It takes as given that the government will always have an important role as standards setter, as monitor, and as the entity that mandates that pension sponsors insure their pension obligations. However, this section raises the question of whether the government must always remain the provider of that insurance, even long after a program of reforms like the one recommended here-designed to substantially eliminate the risk in pension promises-has been put into place. The final section concludes.

\section{A Crash Course in Defined-Benefit Pension Plans}

The textbook DB plan promises each worker covered by the plan a retirement annuity that is determined as a certain percentage (say, $1 \frac{1}{2}$ percent) multiplied by the worker's number of years of service multiplied by the worker's final average salary (perhaps the average over the last three or five years of service). ${ }^{16}$ Two other types of benefits are discussed less

16. Compact and readable summaries of many of the provisions discussed in this section are provided in U.S. Congress Joint Committee on Taxation (2005), CBO (2005a), and Center on Federal Financial Institutions (2004). 
frequently in the economics literature but are disproportionately important from the perspective of the PBGC and will figure in the recommendations put forward below. First, some plans determine promised benefits as a function of years of service only, rather than years of service and salary; some analysts (for example, the Government Accountability Office, or GAO) refer to such plans as "flat-benefit plans," whereas others (for example, Dan McGill) call them "specified dollar benefit plans."17 Benefits in such plans keep pace with prices or nominal compensation only if the nominal amount paid per year of service is adjusted over time. Although such adjustments may occur regularly, they cannot—by law—be prefunded within the plan. As a result, benefit increases in these plans automatically generate new unfunded liability, which under present funding rules may be amortized over thirty years, leaving ample time for sponsors to run aground before the promised benefits have been funded. ${ }^{18}$ In a study of forty-four plans that terminated between 1986 and 1988 (and accounted for 96 percent of the total unfunded liability assumed by the PBGC during those three years), the GAO estimated that flat-benefit plans accounted for $\$ 2.4$ billion, or nearly 90 percent of the $\$ 2.7$ billion in total unfunded liability taken over by the PBGC during that period. ${ }^{19}$

The second, relatively unfamiliar form of benefits is shutdown benefits, which are payable in the wake of an event such as a plant closing or permanent layoff. These benefits may provide access to unreduced retirement benefits at an early age and are no doubt especially important to older workers who, on average, would have a more difficult time transitioning to new employment. The problem with shutdown benefits insofar as the financial viability of the PBGC is concerned is that they are generally not prefunded, because only the expected present value of shutdown benefits is included in plan liabilities, and shutdowns are generally assumed for purposes of computing funding requirements to have zero probability of occurring until they have actually happened. ${ }^{20}$ In a 2003 report the GAO

17. GAO (1992); McGill and others (2005, p. 244).

18. If the ratio of assets to liabilities falls below a certain level ( 90 percent in some cases, 80 percent in others), the plan faces an additional funding requirement intended to speed the amortization of the unfunded liability.

19. GAO (1992, p. 36, note 1). The GAO did not specifically examine the contribution to total insurance losses of recent increases in benefits at these plans. Ippolito (2004) also underscores the importance of flat-benefit plans in generating exposure for the PBGC.

20. GAO (1992, p. 27). 
stated that the "PBGC estimates that it could become responsible for over $\$ 15$ billion in shutdown benefits in PBGC-insured plans," suggesting that shutdown benefits are a noticeable but not predominant source of the PBGC's unsustainable financial position. ${ }^{21}$ Although shutdown benefits are not generally prefunded, they may be fully guaranteed by the PBGC so long as the provision allowing for payment of such benefits had been in place at least five years before the shutdown event. ${ }^{22}$

Under the Employee Retirement Income Security Act (ERISA), private sponsors of DB plans face a welter of regulations governing the minimum contributions they must make to prefund their future retirement obligations. In broad-brush terms, the idea of these regulations is to ensure that sponsors contribute enough each year both to cover that year's benefit accruals ("normal cost" as discussed below) and to amortize a fraction of any gap that may have opened up between assets and liabilities. Certain sponsors - those already in bankruptcy or whose plans are already very deeply underfunded-also face restrictions on their ability to increase promised benefits. In addition, ERISA requires the fiduciary of a DB plan to invest the plan's assets in a diversified manner, but it imposes no requirement that the value of the plan's assets be correlated with the value of its liabilities. Anecdotally, the asset manager is typically instructed only to maximize the expected rate of return on assets for a given level of risk. From the perspective of conventional finance theory, the failure of such instructions to take any account of the characteristics of plan liabilities is odd.

Rules governing the methods that firms must use to report pension-related information in their financial statements are set by the Financial Accounting Standards Board (FASB). ${ }^{23}$ Broadly, pension expense is calculated each period as pension benefits accrued during the period, plus the imputed cost of financing the outstanding pension obligation (calculated using the assumed discount rate), minus the expected return on plan assets, plus the

\section{GAO (2003a, p. 26).}

22. Shutdown benefits, like other benefits, are subject to three distinct forms of guarantee limits. One of these-the one limiting the guaranteeable amount to the normal retirement benefit under the plan-is especially pertinent in the case of shutdown benefits, which may promise a temporary supplement in addition to an unreduced benefit to workers who have not yet reached the normal retirement age.

23. The requirements are set in Statement of Financial Accounting Standard 87, which was promulgated in 1985. A summary is available at www.fasb.org/st/summary/stsum87.shtml. 
amortization of past discrepancies between actual and expected returns and other adjustments such as changes in actuarial assumptions or amendments to plan provisions. The aspect of this treatment that has attracted the most controversy is the fact that sponsors are allowed to report a smoothed version of plan results on their income statement rather than having to reflect changes in the fair market value of assets and liabilities immediately. ${ }^{24}$

The PBGC insures DB plan benefits only up to certain limits, specified in law and detailed below. Both single-employer and multiemployer plans are currently deeply underfunded in the aggregate (with underfunding exceeding $\$ 200$ billion for multiemployer plans, compared with more than $\$ 450$ billion for single-employer plans) ${ }^{25}$ However, under the multiemployer insurance program, the maximum guaranteed benefit is much lower, and employers are jointly liable for the promised benefits. ${ }^{26}$ Consequently, the PBGC has accumulated a much larger negative net financial position under the singleemployer program ( $\$ 23$ billion as of September 30, 2005, as noted above) than under the multiemployer program ( $\$ 335$ million). The PBGC is supposed to be self-financing, and its insurance function explicitly is not backed by the full faith and credit of the U.S. Treasury. ${ }^{27}$

ERISA sets rules governing the permissible means of terminating a DB plan. If a plan is fully funded, the sponsor may close out its obligations by purchasing sufficient annuities from a private insurance company to pay participants their accrued benefits, or by making lump-sum payments

24. See Coronado and Sharpe (2003). FASB is on track to require sponsors to report market value-based estimates of their pension assets and liabilities on the balance sheet itself rather than in the footnotes. Even after this step has been completed, however, the income statement will still be based on smoothed estimates rather than current market values, and the balance sheet estimates will take account of projected increases in wages and salaries, whereas a case can be made (and is made below) that such projections should be ignored. FASB intends to address the treatment of the income statement in a multiyear project due for completion later this decade.

25. PBGC (2005a).

26. Under the multiemployer program, the maximum guaranteed benefit depends on the employee's years of service; at present, for a participant with thirty years of service, the maximum guaranteed benefit is $\$ 12,780$ a year, only about one-quarter the maximum that can be guaranteed under the single-employer program. (See PBGC, "Multiemployer Insurance Program," www.pbgc.gov/media/key-resources-for-the-press/content/page13544.html.) On employer liability under the multiemployer program, see Center on Federal Financial Institutions (2004, p. 2).

27. ERISA $\$ 4002(\mathrm{~g})(2)$ states that "the United States is not liable for any obligation or liability incurred by the corporation [PBGC]." 
to participants; this type of action is referred to as a "standard termination." If a plan is underfunded, the sponsor may terminate it only if the sponsor is in bankruptcy proceedings - either for liquidation or for reorganizationor has persuaded the PBGC that the sponsor would be unable to pay its debts when due and would be "unable to continue in business" unless the plan is terminated, or that the costs of funding the plan have become "unreasonably burdensome" solely because of a decline in the workforce of the sponsor. ${ }^{28}$ For its part the PBGC may terminate a plan if it determines that the "possible long-run loss of the [PBGC] with respect to the plan may reasonably be expected to increase unreasonably if the plan is not terminated." 29

The extent of the PBGC guarantee is limited in several ways. ${ }^{30}$ The restriction with the greatest practical effect is the one that limits the PBGC guarantee to a certain age-related amount per year. For example, for plans terminating in 2006 , benefits will be guaranteed only up to $\$ 47,659$ a year for a participant beginning to draw benefits from the PBGC at age sixty-five (no matter when that person turns sixty-five), and only up to $\$ 30,978$ for a participant beginning to draw benefits from the PBGC at age sixty (no matter when that person turns sixty). ${ }^{31}$ A second limitation on the PBGC guarantee excludes a fraction of benefit improvements implemented within the five years preceding termination: "For benefit

28. 29 U.S.C. $\S 1341(\mathrm{c})(2)(\mathrm{B})(\mathrm{iii})(\mathrm{I}, \mathrm{II})$. The requirements for distress termination are enumerated elsewhere in 29 U.S.C. $\$ 1341(\mathrm{c})(2)(B)$. The conditions for involuntary termination are spelled out in $\S 1342$. In its original form, ERISA did not formally require a sponsor to demonstrate that it was experiencing financial distress before it could put its pension obligations to the PBGC. According to Weaver (1997, p. 146), McGill and others (2005, pp. 806-07, 819), and the CBO (2005a, p. 10), a sponsor could virtually at will put the obligations of the plan to the PBGC in return for 30 percent of the net worth of the firm. However, Boyce and Ippolito (2002, p. 122) state that, notwithstanding the absence of a formal statutory provision so requiring, "in fact, bankruptcy always has been the condition under which the underfunding could be put to the PBGC. This reality was codified in the Pension Protection Act [PPA] of 1987." In a study of plan terminations that occurred between 1983 and 1985, the GAO (1987) found that 96 percent of claims came from sponsors that would have met the distress criteria enshrined in law by the PPA.

29. ERISA $\S 4042(a)(4)$. Note that 29 U.S.C. $\$ 1342$ also includes other criteria for involuntary termination.

30. See PBGC (2000) for a helpful description and analysis of these benefit limitations.

31. PBGC (2005e). The maximum guaranteed amount for plans terminating in 2007 will be marked up according to the rate of change in the same wage index used to escalate the maximum taxable wage amount in the Social Security program. 
improvements that became effective (or that the sponsor adopted, if later) more than one year but less than five years before the plan's termination, the PBGC will guarantee the larger of 20 percent of the benefit increase or $\$ 20$ a month for each full year the increase was in effect." ${ }^{32}$ A third restriction causes the PBGC guarantee to exclude amounts in excess of what the participant would have received from a straight life annuity drawn at the plan's normal retirement age. These limits on guaranteed amounts imply that, even with the backing provided by the PBGC, some workers are at risk of losing benefits in the event of sponsor bankruptcy. ${ }^{33}$

In return for this insurance, plan sponsors pay the PBGC an annual premium, which is calculated in two parts: a flat-rate premium now equal to $\$ 30$ per participant in the plan (indexed for wage inflation beginning in 2007 ), plus a variable-rate premium equal to $\$ 9$ per $\$ 1,000$ of unfunded vested liability. ${ }^{34}$ In practice most unfunded liability is exempted from the variable-rate premium, and so income derived from that provision is far less than 0.9 percent of unfunded liability.

The assets of the PBGC are derived from premium income, assets taken over from terminated plans, and recoveries from employers. The PBGC invests its portfolio almost entirely in a mix of Treasury securities and equities. The investment policy of the PBGC has fluctuated over time; at times it has sought a substantial exposure to equity risk; at other times it has placed much greater emphasis on matching the characteristics of its assets to its liabilities, thereby reducing risk.

The PBGC effectively defines its liability as the price it would have to pay a private entity to assume the financial obligations associated with terminated plans; this concept of liability is known as "termination liability." The PBGC's methodology for estimating termination liability depends importantly on a survey conducted by the American Council of Life Insurers, in which insurance companies are asked to price a range of immediate and deferred life annuities. The PBGC uses these annuity prices to infer a pair of discount rates (one applicable for the first twenty or twentyfive years, the other applicable thereafter) by first positing a mortality table

32. $\operatorname{PBGC}(2000$, p. 11).

33. Although the PBGC guarantees benefits only up to these amounts, it may pay more than the guaranteed amounts if sufficient assets are available (including not only the assets of the plan but also any recoveries from the employer).

34. See PBGC, "PBGC Premiums Rise with Enactment of Budget Reconciliation Bill" (www.pbgc.gov/media/news-archive/2006/pr06-26.html). 
Figure 2. Alternative Discount Rates for Calculating Pension Liability

Percent

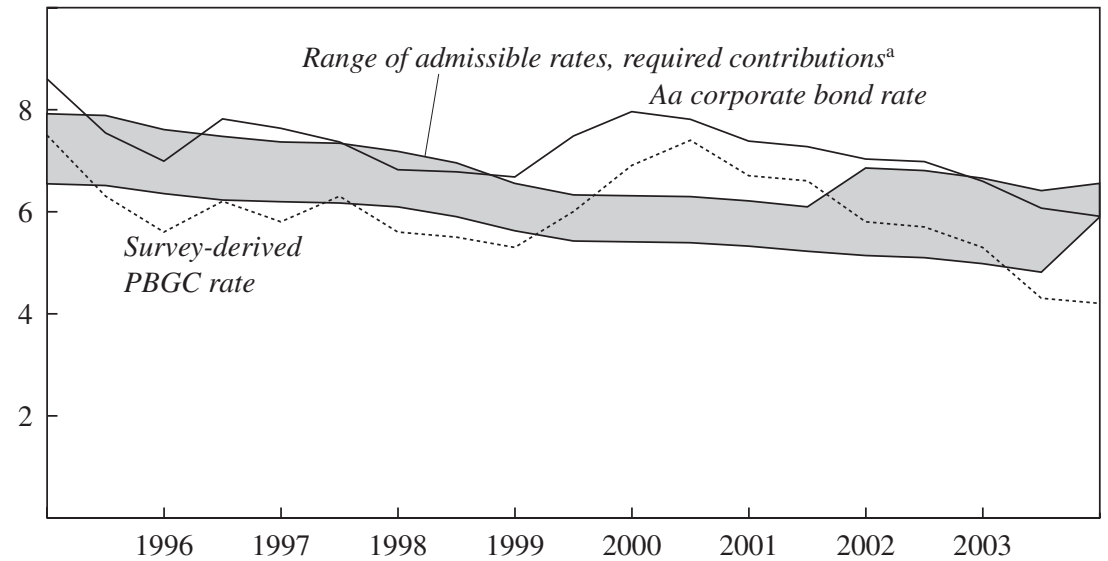

Source: Pension Benefit Guaranty Corporation, Moody's Investors Service.

a. In computing required contributions, firms must choose a discount rate from a range of admissible rates. In computing termination liability they must use the survey-derived PBGC rate. In their financial statements they generally use a rate similar to the Aa corporate bond rate.

and then choosing the two discount rates that best explain the observed annuity prices. ${ }^{35}$ Figure 2 compares the resulting near-term annuity rate with the Aa corporate bond rate-representative of what many corporate sponsors use in preparing their financial statements-as well as the corridor of rates from which sponsors were allowed to choose in calculating required plan contributions. The annuity rate is systematically below the Aa rate but tracks its movements reasonably closely. Between late 2000 and early 2004, however, the annuity rate moved down noticeably more than the Aa rate, implying that, over that period, interest rate declines boosted termination liability by an especially large amount. ${ }^{36}$

35. Helpful descriptions of the PBGC's methodology with regard to termination liability are contained in PBGC (2005b) and GAO (2003d, pp. 24-25).

36. An implication of the PBGC's methodology for measuring termination liability is that the appropriateness of the discount rates used by the PBGC generally cannot be judged in isolation (see PBGC, 2005b, p. 3); one must take account of all the factors influencing annuity prices, including not only discount rates but also assumptions about mortality, lump-sum payments, and early retirement, to name a few. The sample period shown in figure 2 is an exception, because during that period the PBGC was using the same mortality table that private sponsors were required to use in calculating their minimum required contribution; in addition, many private sponsors were using the same table (or one not too unlike it) for purposes of preparing their financial statements. 
In the federal budget the premium income and some investment income of the PBGC are recognized as revenue upon receipt; benefit payments and administrative expenses are treated as outlays insofar as they are deemed to have been funded out of premium income (and the investment income derived therefrom) rather than out of assets recovered from plan sponsors. This budgetary treatment has some unfortunate implications, to be discussed later in the paper.

\section{Some Theory}

As additional background for the design of reforms to the current system, this section presents some simple theory pertaining to three issues that have been much debated among pension analysts: the concept of liability that sponsors should be required to take as their funding objective; the discount rate that sponsors should use in estimating that liability; and the optimal composition of the portfolio of pension assets. The section builds directly on the three axioms stated in the introduction: that the pension promise should be essentially free of risk; that taxpayers should be fully compensated for bearing any residual risk; and that healthy sponsors should not be at risk of having to subsidize unhealthy ones.

\section{What Measure of Liability?}

Two main competing measures of a plan sponsor's liability have been put forward. The first is known as the accumulated benefit obligation, or $\mathrm{ABO}$. The $\mathrm{ABO}$ is computed by determining the benefits to which each employee would be entitled at retirement based on current years of service and current salary, and then discounting these benefits back to the present. The other main gauge of liability is known as the projected benefit obligation, or PBO. The PBO is computed by forecasting future increases in salaries (but not years of service), computing the benefits implied by those forecasts, and then discounting those benefits back to the present. The choice of liability measure is important because it determines both the funding objective and the stochastic characteristics of liabilities (which determine, in turn, the characteristics of the risk-immunizing portfolio of assets). Box 1 further explores the complicated measurement of plan liability. 


\section{Box 1. One Concept, Many Measures: The Different Methods of Calculating Plan Liability under Current Law}

A multitude of different measures of pension plan liability exist, each built up from different assumptions and used for a different purpose. For example, each of several different measures of liability requires that different discount rates be used in their computation:

- Two measures of liability - the one used to determine the basic minimum required contribution, and the one used to determine whether an additional funding requirement is to be assessed — must be computed using a discount rate chosen from within a permissible range.

- The measure of liability that is used to assess susceptibility to the variablerate premium must be computed using a specific discount rate tied to the Treasury rate.

- The measure of liability that firms report in their financial statements is computed using a discount rate of the sponsor's own choosing, usually tied to an index of rates on high-quality corporate bonds.

- The measure of liability used by the PBGC to assess its own net financial position is constructed using a discount rate derived from a survey of insurance companies regarding the prices they charge for annuities.

Figure 2 shows how these different discount rates rose and fell between 1995 and 2004 - the period when, for reasons described in the text, head-to-head comparisons of this type are valid. The differences in movements between these rates, of course, cause the corresponding liability measures to behave differently. Other factors that are important in determining the various estimates of liability differ as well.

The quantitative differences among the various measures can be substantial. Most strikingly, the pension plans at General Motors were underfunded in the aggregate by $\$ 31$ billion as of the end of June 2005 , on a termination liability basis, even though the company's Form 10-K reported them as overfunded by $\$ 3$ billion at the end of 2004 (Mary Williams Walsh and Danny Hakim, "G.M. and a U.S. Agency See Pensions in Different Lights," The New York Times, October 5, 2005, p. C.1). In general, the differences among the various definitions of liability cannot easily be explained as reflecting efforts to answer different underlying economic questions. Apparently, no comprehensive study has been undertaken to identify the most important causes of the discrepancies between the various measures of liability. 
At first blush the PBO seems attractive as a measure of the firm's true economic liability, because it recognizes that, in all probability, at least some workers will remain employed by the firm beyond the present and so will experience further increases in salary; the PBO also reflects the conservative assumption that the plan will be operated on its current terms into the indefinite future. Indeed, some eminent scholars including Fischer Black as well as Deborah Lucas and Stephen Zeldes have argued that firms may appropriately choose to hedge a PBO-based measure of liability. ${ }^{37} \mathrm{On}$ the other hand, Jeremy Bulow and Bodie, among others, have argued that the $\mathrm{ABO}$ is the better measure..$^{38}$ The argument on behalf of the $\mathrm{ABO}$ begins with the observation that if the labor market operated exactly according to the simplest classical model, clearing continuously on the basis of total compensation per worker and with perfect competition, the ABO would be exactly the appropriate economic measure of a firm's liabilities. In the classical model the firm pays its workers their marginal product, period by period. The firm has no incentive to hedge against future fluctuations in any component of compensation, because it is already perfectly hedged against fluctuations in the whole of compensation. One might be concerned that the $\mathrm{ABO}$ approach would expose firms to undue financial stress as their workforces age. But if labor markets clear each period on the basis of total compensation, the high rate of benefit accruals associated with a workforce disproportionately made up of workers near retirement would be offset by slow growth of wages and salaries. Because pension costs are typically a small fraction of total compensation, only a small adjustment in salary is generally required to accommodate fluctuations in pension cost due to changing demographics. ${ }^{39}$

Bulow concedes that if a certain form of implicit contract bound the future actions of workers and firms, the PBO would be the better measure of pension liability. But, on a number of grounds, he expresses skepticism about the likely relevance of such contracts. Furthermore, he argues that even if such contracts did exist, the generosity of a firm's DB plan might

37. Black (1980, 1989); Lucas and Zeldes (2006).

38. Bulow (1982); Bodie (1990b).

39. A separate argument for the $\mathrm{ABO}$ is that firms offering a defined-contribution plan use the ABO approach without controversy. For example, a firm that matches its employees' contributions and automatically steps up their contribution rates each year unless they opt out would account for the cost of the plan on a current basis; it would not use a forecast-based accrual pattern reflecting the trajectory of a typical employee. 
be a poor guide to the empirical importance of the implicit contract at that firm.

Ultimately, the net implication of the choice between $\mathrm{ABO}$ and PBO for the risk that plans present to workers and the PBGC may not be too great: If the $\mathrm{ABO}$ were the economically correct concept but the PBO were nonetheless adopted as the legal standard, the funding objective would generally be higher than with the ABO, providing an extra barrier against risk. On the other hand, the adoption of the PBO as the funding standard might also be taken as justification for investing part of the pension trust in equities, as a hedge against future salary risk. But investing part of the trust in equities would move the portfolio away from immunizing the $\mathrm{ABO}$ - a step that would, all else equal, increase risk. Which of these two influences would predominate is not clear.

\section{What Discount Rate?}

If the $\mathrm{ABO}$ is the funding objective, the liabilities of a plan at any given moment are known in nominal terms, up to demographic risk. If it is further stipulated that demographic risk is not priced, the present-discounted value of liabilities should be computed using the risk-free nominal yield curve. The only question of operational interest is how best to construct an empirical proxy for that yield curve-an issue that is addressed below.

With respect to the appropriate discount rate, two claims quite different from the one put forward here are often asserted. First, it is often argued that because pension sponsors sometimes default on their pension obligations, the pension promises they make should be discounted at a rate appropriate for risky cash flows. After all, plan participants are creditors of the firm just as bondholders are, so why should obligations payable to one be treated any differently from obligations payable to the other? The difference is that the pension trust serves as security for the pension obligations; with a trust of sufficient value and appropriate construction, the pension promises of any sponsor can be rendered free of risk. And to determine whether they are free of risk, those promises should be discounted at a riskless rate even if the general obligations of that sponsor are seen as highly risky.

A second claim contrary to the one put forward here is that the choice of discount rate for future liabilities should be influenced by the nature of the assets held by the pension trust. Indeed, according to Lawrence Bader and Jeremy Gold, the Actuarial Standard of Practice (ASOP) dealing with the 
selection of economic assumptions for pension plans "would generally rule out the use of a near-riskless rate to discount the well-funded pension liabilities of strong sponsors, where the assets are invested in risky securities." ${ }^{\prime 4}$ ASOP 27 reads in part as follows: "Generally, the appropriate discount rate is the same as the investment return assumption." ${ }^{41}$ This is a remarkable statement, because it suggests that plan sponsors can reduce their funding obligations by investing in riskier securities, whereas conventional finance theory would suggest that a given level of benefit security can be maintained despite a shift to a riskier investment portfolio only by increasing, rather than reducing, contributions into the plan.

\section{What Composition of the Asset Portfolio?}

If pension promises are known and must be met with certainty, then the sponsor must hold a core portfolio of sufficient value, invested so as to immunize the risk of its liabilities. The sponsor could, of course, hold a portfolio of greater value than the required minimum, in which case the surplus value would not have to be held in the immunizing asset. ${ }^{42}$ But the sponsor may not hold less than the required minimum amount and may not invest any of that required minimum in any asset other than the immunizing asset-in this case, bonds structured to deliver their cash flows as the pension obligations come due. As Bodie points out, ${ }^{43}$ an all-bonds portfolio has the additional advantage from the sponsor's perspective of maximizing the benefit associated with the tax-preferred status of the pension fund.

\section{Other Issues}

The triplet of prescriptions identified here-fund to the $\mathrm{ABO}$, discount using the risk-free rate, and either purchase deferred annuities or invest the pension trust in nominal bonds designed to mature as the pension obligations come due-provides an internally consistent set of answers to the three questions posed at the beginning of this section. Moreover, if the objective is to render the pension promise essentially free of risk, and if the market

40. Bader and Gold (2003, p. 11, note 16). The claim here, of course, is even stronger: that a near-riskless rate should be used to discount even the well-funded pension liabilities of weak sponsors.

41. Pension Committee of the Actuarial Standards Board (1996, p. 5).

42. Bodie (1990a, p. 16).

43. Bodie (1990a). 
for labor were perfectly competitive and frictionless, these answers would be exactly correct. Given the importance of the issue, it is a little surprising that the literature seems not to have progressed much beyond these statements. As noted earlier, Bulow addresses the possibility that implicit contracts govern the life-cycle pattern of compensation, but he sees such contracts as probably not very relevant and in any event not well indexed by the size of the DB plan. ${ }^{44}$ To my knowledge there has been no examination of the quality of the approximation provided by the ABO-based triplet in other market contexts, such as where efficiency wages are important.

If the reforms recommended here were to be implemented, the pension promise would be a risk-free obligation except for demographic risk. In that case the market value of a firm's pension liabilities would appropriately be measured using the yield curve of risk-free rates, regardless of the creditworthiness of the sponsor. That would be a simpler world, because the same measure of liability would be relevant for pension regulators, participants in bankruptcy proceedings, and securities analysts attempting to estimate the value of individual firms.

Given that the reforms recommended here have not been implemented, however, the situation is not so simple, and one can imagine several alternative interesting measures of pension liability, each relevant from the perspective of a different stakeholder. From the perspective of the government, a measure of interest is the present-discounted value of benefits guaranteed by the PBGC. Assuming that the taxpayer will ultimately step in, if necessary, rather than allow the PBGC to default on its stated obligations, this measure of liability should be computed using a yield curve of risk-free rates. From the perspective of financial analysts and investors, a measure of interest is the present-discounted value of the sponsor's liability. This measure should be computed using a discount rate that reflects not only the risk-free rate but also the ratio of assets to liabilities in the plan, the extent to which the assets of the plan have been invested so as to immunize the liability risk of the plan, and the creditworthiness of the sponsor. ${ }^{45}$ From the perspective of the worker, a measure of interest is the market value of the benefits that workers will receive under the plan. This measure can fall no lower than the amount guaranteed by the PBGC, but it also

44. Bulow (1982).

45. These are the same factors that determine the value of the option held by the firm to put the obligations of the plan to the PBGC. 
includes a call option on the assets of the plan with a strike price equal to the guaranteed amount. Obviously, once one steps outside the world of perfect certainty, the range of potentially interesting measures of liability becomes much greater. However, the range is not unlimited, and a common feature of the measures described above is that they each attempt to answer a well-defined economic question. It is not apparent that the same can be said of each of the measures of pension liability currently in use.

\section{The Anatomy of Plan Failure}

Viewed from a sufficiently high altitude that the messiness of the details fades from view, the pension landscape described earlier in this paper has a generally sensible aspect. Barring a waiver from the IRS, sponsors are required to contribute enough each year both to fund their normal cost for that year and to amortize a portion of any unfunded liability that the plan may have accumulated. Sponsors of plans with especially deep underfunding face an additional funding requirement intended to accelerate their progress toward full funding. Taxpayers shoulder a contingent liability associated with their backstopping of private plans, but they are compensated in a way that is at least loosely tied to risk. All in all, therefore, the system has clearly been configured with an eye to limiting the risk borne by both beneficiaries and taxpayers while providing some flexibility to employers. Yet, as already noted, the PBGC currently reports a net financial position of $-\$ 23$ billion and is likely, in the view of most analysts, to encounter even greater financial difficulty in the years ahead. Thus the question: In practice, what features of the current pension environment have allowed some plans to get themselves into desperate financial condition, causing some of them ultimately to default on promises to workers, generate large obligations for the government insurance program, and put surviving sponsors at risk of having to bear more than their economically fair load?

No recent study has attempted to quantify the contributions of specific features of the current system to the deficit status of the PBGC, but in congressional testimony Steven Kandarian, former director of the PBGC, pointed to several key factors without attaching numerical estimates. Among those factors were the following: ${ }^{46}$

46. Kandarian (2003, pp. 4-7). 
-Pension plan assets have not been structured so as to mimic the characteristics of plan liabilities. As a result, the "unprecedented, concurrent drops in both equity values and interest rates" experienced by plans in recent years both eroded the value of assets and inflated the value of liabilities.

- The additional funding requirement faced by severely or chronically underfunded plans stops rising when such plans reach a funding ratio (that is, the ratio of assets to liabilities) equal to 90 percent rather than 100 percent, leaving plans with less than they would need to make good on all obligations if the plan were to be terminated immediately.

- The definition of current liability fails to "recognize the full cost of providing annuities as measured by group annuity prices in the private market." In other words, on average, the combination of discount rates, retirement ages, and mortality rates assumed by firms results in too low an estimate of plan obligations, and hence of the appropriate level of plan funding.

- The definition of current liability also fails to recognize the increased tendency, as a plan veers toward termination, of workers to draw subsidized early-retirement benefits and lump-sum payments.

- Credit balances allow some sponsors to make smaller contributions, or no contributions at all, even as their plans head toward termination.

- The limit on the maximum deductible contribution inhibits sponsors from "build[ing] up an adequate surplus in good economic times to provide a cushion for bad times."

From time to time the GAO has taken a more quantitative approach to assessing the causes of large claims on the pension insurance fund. Although the most comprehensive of these studies is now nearly two decades old ${ }^{47}$ it may still shed useful light on the current situation. In that study the GAO estimated that about 70 percent of new claims on the PBGC between 1983 and 1985 reflected funding rules that were too lax, partly because they allowed benefit improvements to be amortized over thirty years. The GAO attributed the remainder of the claims to the fact that required contributions were not always paid before a plan terminated. Of the amount the GAO classified as required but unpaid, nearly half reflected required contributions that had not yet come due (because payments are not due until $81 / 2$ months after the close of the relevant plan year), about a third stemmed from arrears, and the remainder reflected amounts that had been waived by the IRS.

47. GAO (1987). 
In two more-recent studies, ${ }^{48}$ the GAO concentrated on a few terminations that generated large claims on the PBGC; these studies corroborated a number of the points made by Kandarian. Several of the illustrations given by the GAO pertained to the termination of plans sponsored by Bethlehem Steel. With respect to the role of equity investments, the GAO noted that as of September 30, 2000, Bethlehem had 73 percent of the assets in its DB plan invested in equities. Over the following year the value of plan assets declined 25 percent, and by the time the plan terminated a little more than a year after that, the value of plan assets had declined another 23 percent. ${ }^{49}$ Credit balances also played an important role in the Bethlehem narrative. The GAO reports that, one year before termination, Bethlehem faced a minimum required contribution of $\$ 270$ million. ${ }^{50}$ Yet in the three years preceding the termination of its plans, Bethlehem was able to avoid contributing any new resources by drawing on its credit balance. ${ }^{51}$ The Bethlehem experience also sheds some light on why termination liability often exceeds current liability. For the purpose of calculating current liability, Bethlehem participants eligible for unreduced benefits after thirty years of service were assumed to retire at age sixty-two; for the purpose of calculating termination liability, however, they were assumed to retire at age fifty-five. The GAO cited the PBGC as estimating that the difference in assumed retirement ages approximately doubled the liability of the plan for benefits payable to those participants. ${ }^{52}$

Separately, the GAO highlighted the extent to which firms have been exempted from paying the variable-rate premium. The GAO focused on three plans that terminated in 2002 and 2003; none of these plans paid a variable-rate premium in 2001, because they qualified for the exemption available to any sponsor whose contribution into the plan in the previous year was at the so-called "full funding limit," explained in more detail in the following section. ${ }^{53}$ Finally, the GAO noted a possible role of the limit on deductible contributions in holding down the contributions of Polaroid to its plan: As of January 1, 2000, Polaroid's DB plan had a funding ratio

\footnotetext{
48. GAO (2003b, 2003c).

49. GAO (2003b, p. 7).

50. GAO (2003b, p. 12).

51. PBGC (2005g).

52. GAO (2003c, p. 21).

53. GAO (2003c, p. 22).
} 
of more than 100 percent, and "The plan's actuarial report for that year indicates that the plan sponsor was precluded ... from making a taxdeductible contribution to the plan." ${ }^{54}$ A little more than two years later, the plan was terminated with a funding ratio of 67 percent based on termination liability.

In yet another study, the GAO highlighted the importance of claims from flat-benefit plans: "Most of the claims against PBGC's single-employer program have come from 'flat-benefit' plans that cover hourly workers in unionized companies." "55 The GAO did not quantify "most," nor did it rule out that the other factors discussed above had also played a role in generating large claims. Elsewhere the GAO describes various forms of moral hazard as having increased claims against the PBGC; these include increasing promised benefits, forgoing contributions either legally by waiver or illegally, and selling "a subsidiary with an underfunded plan to a financially troubled buyer." ${ }^{56}$ No quantitative estimates of the importance of these effects were provided.

\section{The Nuts and Bolts of Pension System Reform}

All in all, the roster of weaknesses in the current DB pension system looks rather deep. The system is in need of reform in all its major dimensions: funding requirements, portfolio investment restrictions, insurance premiums, and disclosure. Unless substantial reforms are undertaken, each of the three major constituencies involved in the system will continue to bear needless costs: Workers will confront needless uncertainty regarding their future financial security; healthy sponsors will continue to face the risk of having to subsidize unhealthy ones; all sponsors will operate in a regulatory regime imposing unnecessary costs; and taxpayers will continue to subsidize the pension deal between workers and firms in a manner that is not widely understood and to a degree that is difficult to estimate.

54. GAO (2003c, p. 22). As the GAO notes, Polaroid assumed the highest allowable interest rate in computing its liability for purposes of determining its funding requirement. Had Polaroid used a lower interest rate, and hence generated a larger estimate of its liability, the corporation might have been able to make a deductible contribution.

55. GAO (1998, p. 9).

56. GAO (1998, p. 17). 
Specifically with reference to the PBGC, the problem has two dimensions, one backward-looking and one forward-looking. The backwardlooking problem is that the insurance fund has already sustained substantial net losses from its operations thus far. This problem is much bigger than the negative net financial position already reported by the PBGC, in that sponsors have in effect accumulated put options that have considerable value under current law. To deal with this overhang, three alternative approaches are logically possible, none of which is attractive: taxpayers could foot the bill; surviving sponsors could be made to pay premiums that exceed the economically fair level; or the PBGC could default on its obligations. Of these three, the first has the virtue of making good on the government's promises as they are commonly understood while still allowing PBGC insurance to be fairly priced on a prospective basis; thus it would avoid distorting employers' decisions as to whether to sponsor or continue sponsoring DB plans. In the words of the CBO, "Conceptually and practically, the prospective approach [calibrating premiums to future risks rather than accrued losses] has several advantages. The idea of a fair insurance premium is intrinsically forward-looking: it is the expected cost of future adverse outcomes covered under the terms of the insurance policy." ${ }^{57}$ In a competitive market for plan termination insurance, any provider attempting to raise premiums above their economic level would be undercut by other providers willing to price at marginal cost on a prospective basis. Moreover, regardless of the market structure on the provider side, boosting premiums above their economic level would impose an excess burden on surviving sponsors, heightening the risk of an exodus from the DB system.

The PBGC's forward-looking problem is that it will, in all probability, continue to accrue net economic losses so long as it continues to operate under current parameters. To remedy this situation and to ensure that the conditions implied by the three axioms laid out in the introduction are met, actions would have to be taken in three broad areas: funding and portfolio investment rules would have to be tightened; the pricing of the PBGC's insurance would have to be rationalized; and the information provided about DB plans-in firms' public financial statements, in the federal budget, and to workers-would have to be improved. In principle, a thorough implementation of the recommended steps in any one of these three areas might be sufficient to right the ship without any reform in the other two

57. CBO (2005b, p. 8). 
areas. For example, an ideal system of risk-sensitive premiums might lead sponsors to fully fund their plans and immunize their liability risk. Alternatively, a perfect system of public disclosure might so enhance market discipline as to induce sponsors to aim for full funding and complete immunization. Despite these possibilities, the approach taken here is to recommend fundamental changes in all three areas. This approach deliberately involves a degree of redundancy — belt, suspenders, and bungee cords - on the theory that not all reforms may be implemented simultaneously and that, even if all were implemented and functioned as intended, the cost of redundancy would be small and might be zero. ${ }^{58}$ For example, a sponsor with a fully funded and immunized plan would not have to pay any insurance premium except, perhaps, for a base amount to cover PBGC administrative expenses.

The First Locus of Reform: Funding Requirements, Limitations on Benefit Increases, and Portfolio Investment Restrictions

DETERMINATION OF REQUIRED CONTRIBUTIONS: CURRENT LAW. Required contributions today depend on four main factors: normal cost, supplemental liabilities that are amortized over several years rather than funded in full immediately, an additional funding requirement faced by sponsors of severely or chronically underfunded plans, and various exemptions from and disincentives for additional funding.

A plan's normal cost in a given year is the amount of benefits attributed under its funding method to that year. Many different methods for computing normal cost have been developed, each of which allocates costs differently over time. Treasury regulations disallow methods that allocate these costs in a manner that is deemed to be too back-loaded. In the simplest of all possible worlds, setting contributions equal to normal cost each year would cause assets to keep pace with liabilities and thus cause the plan to remain fully funded.

Every forecaster knows, however, that history never unfolds exactly as projected: Rates of return, mortality, and salary growth differ from their assumed values; actuarial assumptions are adjusted; plan provisions are

58. Bodie and Merton (1993) and Bodie (1996) emphasize the complementarity of the tools discussed here. They also emphasize the importance of improving the PBGC's ability to monitor plan sponsors and the inadequacy of the PBGC's current tools in this regard-topics not addressed here. 
changed; and sponsors grant benefits based on service before plan inception. All of these eventualities create gaps between assets and liability. Such gaps are amortized over various periods depending on the source of the discrepancy, as shown in the table below: 59

\begin{tabular}{lc}
\hline Source of unfunded liability & Amortization period \\
\hline $\begin{array}{l}\text { Experience gains and losses (deviations of } \\
\text { rates of return, mortality, and other }\end{array}$ & 5 years \\
$\quad$ factors, from assumptions) & \\
Changes in actuarial assumptions & 10 years \\
Plan amendments & 30 years \\
Initial unfunded liability, for plans & 30 years \\
$\quad$ established after January 1,1974 & \\
\hline
\end{tabular}

The idea of these amortization charges and credits is to continuouslyalbeit slowly — nudge assets back into line with liability.

Single-employer plans with more than 100 participants may face an additional funding requirement (AFR) if they are either severely or chronically underfunded. ${ }^{60}$ Whether a plan is subject to an AFR is determined by the plan's funding ratio. If either the funding ratio is less than 80 percent, or the funding ratio is between 80 and 90 percent and has not been above 90 percent in two consecutive years within the past three, the plan is subject to the AFR. Sweeping aside many details, the AFR is determined roughly as follows:

$\mathrm{AFR}=$ unfunded liability $\times$ amortization fraction,

where the amortization fraction is 18 percent for plans with a funding ratio of 90 percent, 30 percent for plans with a funding ratio of 60 percent or lower, and linearly interpolated for plans in between. Thus the AFR is

59. McGill and others (2005, p. 686).

60. The additional funding requirement was introduced in the Omnibus Budget Reconciliation Act of 1987 (see GAO, 1994, p. 2) and amended in the Retirement Protection Act of 1994, enacted as part of P.L. 103-465. Current statutory requirements are specified in 26 U.S.C. §412(1). See McGill and others (2005, pp. 689ff.) for a helpful description of the requirements. Regarding the actuarial value of assets, see 26 U.S.C. $\$ 412(\mathrm{c})(2)(\mathrm{A})$. Treasury Department regulations (26 C.F.R. §1412(c)(2)-1) fill in the details and specify that the actuarial value may not stray too far from the fair market value or run consistently above or below both the current fair market value and a moving average of same. 
intended to cause plan sponsors with severely or chronically underfunded plans to contribute enough each year, in total, both to fund their normal cost in the given year and to accelerate their progress in closing any gap between assets and liabilities. Note, however, that the accelerated gap closure intended under the AFR applies neither to any plan with a funding ratio in excess of 90 percent nor to many plans with funding ratios between 80 and 90 percent. In a study of the 100 largest plans between 1995 and 2002, the GAO found that only about three plans per year, on average, were assessed an AFR, despite the fact that about ten plans per year had funding ratios of less than 90 percent. ${ }^{61}$

Two other provisions allow firms to contribute less than the amounts indicated above, two more limit their incentive to contribute in excess of the minimum required amount, and a final provision allows funding requirements to be waived altogether under some circumstances:

-Credit balances. The difference between actual and minimum required contributions is cumulated-together with imputed interest earnings-in a hypothetical account called the funding standard account (FSA). ${ }^{62}$ Firms that have, on net, contributed more than the required minimum have a credit balance in their FSA, which they can use to offset current or future required contributions. Credit balances have enabled some distressed sponsors (such as Bethlehem Steel, as discussed above) to defer required contributions during the run-up to bankruptcy, arguably causing the PBGC to absorb a greater loss.

-Full funding limit. ERISA sets a cap — known as the full funding limit, or FFL — on the amount that sponsors may be required to contribute in any given year. When it binds, the FFL causes the required contribution to fall short of the amount indicated by the plan's normal cost, amortization charges, and AFR. The following is a stylized version of how the FFL has been determined since 2004:

$$
\mathrm{FFL}=\max [\mathrm{AL}-\min (\mathrm{MVA}, \mathrm{AVA}),(0.9 \times \mathrm{CL})-\mathrm{AVA}],
$$

where AL is accrued liability (which may be computed taking projected future salary increases into account), MVA is the market value of assets,

61. GAO (2005, p. 25).

62. McGill and others (2005, p. 687) and 29 U.S.C. §1082(b)(2). 
AVA is the actuarial value of assets, and CL is current liability. ${ }^{63}$ Roughly, the idea of the FFL is to shield sponsors from having to contribute more to their plans than would cause their plans to be fully funded as defined in the law. Given that the spirit of the other funding rules is to ensure that sponsors fund their normal costs and close a fraction of any existing funding gap, it might seem counterintuitive that a firm could, in the absence of the FFL, have been required to make a contribution that would have taken assets above liability, but such an outcome is possible given the variety of definitions of assets and liability involved in the various determinations.

- Maximum deductible amount. Pension contributions may be deducted from income for tax purposes, up to a limit specified in law. ${ }^{64}$ As was noted earlier, the determination of the maximum deductible amount is so complex as to be more easily illustrated than described (see figure 1 above). Amounts contributed in excess of the maximum deductible amount are subject to a 10 percent excise tax.

-Limitations on reversions of plan assets. Generally speaking, surplus pension assets may not be withdrawn from the trust unless the plan has been terminated and all the liabilities of the plan have been met. In the event of termination, surplus assets may revert to the sponsor but must be included in the sponsor's taxable income (thereby unwinding the original tax deduction) and are subject to an excise tax of between 20 and 50 percent. ${ }^{65}$ This excise tax creates a strong incentive for financially distressed sponsors to ensure that their plans are not materially overfunded and thus have no buffer against unforeseen developments.

-Waivers. If a plan sponsor would be unable to meet the minimum funding standard "without temporary substantial business hardship . . . and if application of the standard would be adverse to the interests of plan participants. ..," the IRS may waive some or all of the required contribution except for the amount required to amortize any previous waivers. ${ }^{66}$ Waived contributions must be amortized over five years, beginning in the

63. See U.S. Congress Joint Committee on Taxation (2005, pp. 30-31). Between 1995 and 2003 the cap on required contributions was set as follows: FFL $=\max [\min (\mathrm{AL}, \alpha \mathrm{CL})-$ $\min (\mathrm{MVA}, \mathrm{AVA}),(0.9 \times \mathrm{CL})-\mathrm{AVA}]$, where $\alpha$ was 165 percent in 2002 and 170 percent in 2003.

64. See U.S. Congress Joint Committee on Taxation (2005, p. 34).

65. U.S. Congress Joint Committee on Taxation (2005, pp. 19-20).

66. Requirements with respect to waivers and criteria for the determination of "business hardship" are spelled out in 26 U.S.C. §412(d). 
year following the waiver, and no more than three waivers may be obtained in any fifteen-year period. ${ }^{67}$

DETERMINATION OF REQUIRED CONTRIBUTIONS: PROPOSED REFORMS. To minimize the risk presented to workers, taxpayers, and healthy sponsors, in line with the axioms stated in the introduction, sponsors should be required to fund benefit accruals each year plus amortize any shortfalls or surpluses over a reasonably short period, all on a mark-to-market basis. ${ }^{68}$ Implementation of this objective would require the following changes relative to current law:

- The method of calculating plan liability for purposes of determining required contributions should be greatly streamlined. The simple theory sketched earlier suggests that a single measure of liability, defined on an $\mathrm{ABO}-$ type basis and calculated using discount rates taken from an empirical proxy for the risk-free yield curve, should be sufficient.

-All gaps between assets and liability should be amortized over some uniform and reasonably short period-perhaps on the order of five or seven years-regardless of the sources of those gaps. ${ }^{69}$

- The AFR should be eliminated, taking with it the associated funding volatility and administrative complexity.

-Increases in flat-dollar benefits should either be treated as part of normal cost, in line with the treatment of increases in salary-linked benefits, or be amortized over the same reasonably short period applicable to all other sources of underfunding.

- Shutdown benefits and improvements in plan benefits should likewise be amortized over the uniform period.

67. VanDerhei (1990) is the only study of which I am aware that attempts to quantify the importance of waivers in boosting the ultimate demands on PBGC resources. Using data from Form 5500 filings, he identified 115 waivers granted in 1980 and 1981; the waived amounts totaled $\$ 622$ million. By 1987, 20 percent of the sponsors that had been granted waivers in 1980 and 1981 had terminated their plans. Claims from these sponsors totaled \$136 million, but VanDerhei attributed only \$26 million of that amount to the waivers that had been granted in 1980 and 1981 . Thus he computed a loss ratio of only 4.2 percent for the waivers from this period.

68. Gold (2005, p. 93) sketches a similar reform objective: “. . . any long-term solution must require full funding of accrued liabilities (measured at riskless rates) at all times."

69. If assets were invested so as to immunize liability risk, as recommended below, a key source of discrepancy between assets and liability would be removed. Remaining sources would include experience gains and losses (outcomes that differ from actuarial assumptions) and amendments to plan provisions. 
-Whatever length of time is chosen as the period over which funding shortfalls will be amortized should also become the length of time over which the PBGC guarantee becomes effective. Thus, for example, if shutdown benefits are amortized over five years, the guarantee of those benefits should be phased in over five years, measured not from the time when the shutdown provision was added to the plan, as under current law, but from the time when the shutdown was recognized by the actuary for the plan. ${ }^{70}$ The same general approach should apply for other improvements in benefits.

- Currently, a sponsor that offers subsidized early-retirement benefits or subsidized lump sums may be vulnerable to a "run on the bank" if participants come to suspect the financial viability of the plan. To eliminate that vulnerability, the subsidized portion of early-retirement benefits and lump sums should be paid out of funds other than those held in the pension trust, and the subsidy portion should not be insured by the PBGC.

-A plan should be frozen automatically when the sponsor is delinquent in making a contribution and should remain frozen until the sponsor has eliminated any arrears.

-Assets should be valued at current market prices, and firms should no longer be able to use credit balances in the FSA to reduce their required contributions.

- The FFL on required contributions should be eliminated.

Sponsors often highlight the limit on tax deductibility and the excise tax on pension fund reversions as factors inhibiting them from funding up their plans in flush financial times. Some relaxation of these constraints may be in order, but two considerations suggest that any steps in this direction should be modest: First, the motivation for the constraint on tax deductibility is to limit the loss of tax revenue that sponsors are able to engineer by shifting the timing of their pension contributions; that motivation remains legitimate. Second, the reforms outlined here would move sponsors a long way toward contributing their normal cost year in and year out. By eliminating the bulk of the volatility in funding requirements, these reforms arguably would also eliminate most of the need to manage the timing of contributions and most of the need for a cushion of assets in excess of the required minimum.

70. GAO (2003b) makes a suggestion along these lines. 
An important issue related to the design of funding requirements is how best to construct an empirical proxy for a yield curve appropriate for risk-free cash flows. One possibility would be to use quotes from the market for Treasury securities. A Treasury yield curve would have two disadvantages in this context: first, that the underlying securities are tax-advantaged and thus less preferred by pension funds given their tax-exempt status; and second, that prices in the Treasury market incorporate a premium for liquidity - another characteristic that may be of relatively little importance to pension funds given their typical investment horizons. A second possible approach is the one currently used by the PBGC, which calculates a pair of discount rates based on a survey of annuity prices. This approach has the appeal of being tied very directly to the existing private market for this type of obligation, but the disadvantages of involving a relatively opaque process and of dealing only crudely with the time structure of the liabilities. A third possibility that warrants serious investigation would be to use the yield curve implicit in the market for swaps between floating-rate and fixed-rate debt. These rates have the disadvantage of including a small premium for credit risk, but that premium seems unlikely to be more than 50 basis points, and thus hardly disqualifying. Moreover, swaps based on the London interbank offer rate (LIBOR) have the advantage of trading in an active and highly transparent market.

RESTRICTIONS ON THE ABILITY OF SPONSORS WITH UNFUNDED LIABILITIES TO INCREASE BENEFITS: CURRENT LAW. If a proposed plan amendment would increase the current liability of the plan and leave the funding ratio of the plan below 60 percent, the sponsor must provide security in an amount specified by law. ${ }^{71}$ Similarly, a plan sponsor in bankruptcy may not amend a plan in a way that would increase plan liabilities "by reason of any increase in benefits, any change in the accrual of benefits, or any change in the rate at which benefits vest under the plan." 72 Plan amendments that would leave the funding ratio above 60 percent are not constrained so long as the sponsor is not in bankruptcy proceedings.

RESTRICTIONS ON THE ABILITY OF SPONSORS WITH UNFUNDED LIABILITIES TO INCREASE BENEFITS: PROPOSED REFORMS. Aligning the uniform amortization period with the period over which the PBGC guarantee is phased

71. See 26 U.S.C. §401(a)(29) and U.S. Congress Joint Committee on Taxation (2005, pp. 32-33).

72. U.S. Congress Joint Committee on Taxation (2005, p. 33). 
in should provide full protection to the insurance program from the risk associated with benefit increases; it should also provide substantial protection to workers. The restrictions on benefit increases embodied in current law could be retained, although they should become substantially irrelevant if and as the incidence of deep underfunding is eliminated.

PORTFOLIO INVESTMENT RESTRICTIONS: CURRENT LAW. The fiduciary of a DB plan is required to "[diversify] the investments of the plan so as to minimize the risk of large losses, unless under the circumstances it is clearly prudent not to do so." ${ }^{\text {"73 }}$ Fiduciaries are not required under current law to immunize the risk in the liabilities of the plan; evidently, in fact, almost no consideration is given in statute or regulation to requiring that the fiduciary take any account of the characteristics of plan liabilities in designing the portfolio of assets..$^{74}$ Coronado and Liang report that, in 2003, "about two-thirds of the firms [in their sample] allocated between 60 and 75 percent of their DB assets to equity securities. Similarly, two-thirds of the firms allocated between 20 and 35 percent of the portfolio to fixed income securities. ${ }^{"} 75$ In the aggregate, as figure 3 shows, pension plans in 2003 held about 60 percent of their assets in equities. According to the investment management firm PIMCO, "the 100 largest U.S. defined benefit pension plans [as of 2002 were] unhedged on more than 90 percent of their interest rate exposure." 76 Anecdotally, I am aware of only two firms having used their assets to immunize liability risk: Boots, a British pharmaceutical retailer, which is said to have backed off this policy, and United Airlines, which is reported to have abandoned the strategy in the mid-1980s. ${ }^{77}$

PORTFOLIO INVESTMENT RESTRICTIONS: PROPOSED REFORMS. If firms are to immunize their liability risk to the maximum practical degree, they should hold very high quality debt instruments structured to deliver their

73. 29 U.S.C. $\$ 1104(a)(1)$. McGill and others (2005, p. 742) note that, notwithstanding the diversification requirement, the fiduciary of the plan may invest all of its assets in "insurance or annuity contracts guaranteed by a life insurance company or wholly in the securities of the federal government or its agencies."

74. The only exception of which I am aware is that sponsors are required to take account of the liquidity needs of the plan - in other words, to ensure that any assets held are sufficiently liquid as to be available to pay benefits as they come due.

75. Coronado and Liang (2005, p. 9).

76. Ruthen (2005).

77. Mary Williams Walsh, "How Wall Street Wrecked United's Pension," The New York Times, July 31, 2005, p. 3.1. 
Figure 3. Allocation of Aggregate Defined-Benefit Pension Assets in 2003

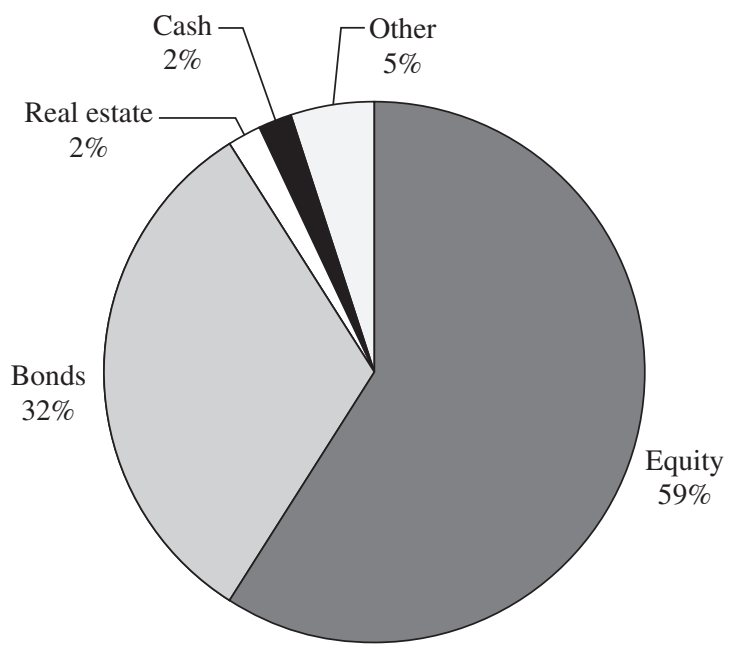

Source: Data from Coronado and Liang (2005).

cash flows as the benefit obligations come due. In practice, such debt instruments should probably consist mainly of very high quality private securities. If the demand for such instruments were to expand dramatically, one could expect borrowing firms to cater to that demand by adjusting their capital structures, and financial markets to repackage existing debt by slicing it into senior tranches suitable for pension fund investors and junior tranches for other investors better positioned to shoulder credit risk.

PORTFOLIO INVESTMENT PRACTICES OF THE PBGC AT PRESENT. The assets of the PBGC are maintained in two separate funds: An on-budget revolving fund receives premium income and is the source of benefit payments, and an off-budget trust fund receives assets taken over from terminated plans and recoveries from employers. Transfers are made from the trust fund to compensate the revolving fund for benefit payments deemed to have been backed by assets taken over from the sponsor. The PBGC invests the revolving fund entirely in Treasury securities, but it invests a portion of the trust fund in equities, including actively managed equities. As of September 30, 2005, the revolving fund amounted to $\$ 16.4$ billion while the trust fund held $\$ 32.6$ billion. The share of the portfolio invested in equities has fluctuated over the years. At the end of fiscal 2005 that share 
was about 25 percent, down from about 30 percent one year earlier; cash and fixed-income securities made up virtually all of the rest. The reduction in the equity share reflected a deliberate decision on the part of the PBGC to increase its use of fixed-income securities to immunize its liabilities. Under that policy the PBGC will eventually reduce its equity holdings to between 15 and 25 percent of its portfolio. ${ }^{78}$

PORTFOLIO INVESTMENT PRACTICES OF THE PBGC: PROPOSED REFORMS. The liabilities of the PBGC derive from plans already terminated and thus are not adjusted for further increases in service or salary; effectively, they are known in nominal terms, up to mortality risk. Presumably, the PBGC should conduct itself as if it will be required to meet its obligations with certainty. Under that assumption the cost-minimizing (and therefore valuemaximizing) method of operation is for the PBGC to invest its assets entirely in long-dated zero-coupon bonds structured to mature as the obligations of the terminated plans come due. ${ }^{79}$ Bodie provides a particularly simple and elegant demonstration of the proposition that the immunizing portfolio meets the obligation with certainty at minimum cost. ${ }^{80}$

WOULD THE PROPOSED REFORMS REDUCE THE VOLATILITY OF REQUIRED CONTRIBUTIONS? Plan sponsors express great concern about the volatility of required contributions under current law. Several of the reforms proposed here would eliminate mechanisms that sponsors have viewed as useful in reducing that volatility. (The relaxation of the constraints on tax deductibility is the exception, as it would be viewed as allowing firms greater flexibility to fund up their plans when times are good.) But the volatility of contributions is entirely a choice of plan sponsors. Bader and Gold point to the obvious first step for sponsors seeking to reduce funding volatility: "Asset-liability matching can sharply curtail the volatility of financing gains and losses, and the purchase of deferred annuities can

78. See PBGC (2005f, p. 14).

79. Because it receives a continual flow of assets from terminated plans, and because the liquidation of those assets takes at least a little time, the PBGC will not be able to boost the measured share of fixed-income securities in its portfolio to 100 percent so long as sponsors are permitted to hold substantial fractions of their portfolios in equities. If sponsors immunized their liability risk, an all-bond portfolio would be cost-minimizing for the PBGC, notwithstanding the fact that additional plans would be terminated in the future. If sponsors continue to carry unhedged equity risk, conventional finance theory would suggest that the PBGC should hold a short position in equities.

80. Bodie (2005). 
eliminate it." ${ }^{81}$ If even the remaining volatility—which would derive from the influence of interest rate changes on normal cost-proved intolerable to sponsors, they could render their funding requirements essentially entirely predictable from year to year by redefining the promised benefit under the plan. For example, they could structure their plans so that a fixed percentage of salary would be contributed each year and used to purchase deferred fixed (though possibly inflation-indexed) annuities in whatever amount the market would provide under current conditions. ${ }^{82}$ Equivalently, the plan could self-insure by building a duration-matched portfolio of bonds. Either way, the sponsor could achieve complete control over pension costs (through its control over the salary deferral rate) and completely eliminate funding volatility. At the same time, some of the critical features of the DB model would have been preserved: Workers would be given access to the annuity market at group rates; the security of the retirement promise would have been enhanced; and a considerable degree of predictability about the amount of retirement income to be provided through this means would have been retained.

\section{The Second Locus of Reform: Pricing of PBGC Insurance}

DETERMINATION OF INSURANCE PREMIUMS: CURRENT LAW. As was outlined earlier, the PBGC receives premium income in return for the insurance it provides. Under ERISA as originally enacted, the only form of premium was a flat-rate fee of $\$ 1$ per year per participant. ${ }^{83}$ The flat-rate premium was increased in several steps during the 1980s before reaching $\$ 19$ per year per participant in 1991. The flat-rate premium remained at its 1991 level in nominal terms (and thus obviously declined substantially in real terms) until it was raised to $\$ 30$ in the budget bill enacted in early 2006. A variable-rate premium was added in 1987 , assessed initially at $\$ 6$ per $\$ 1,000$ of unfunded vested liability and capped at $\$ 34$ per participant

81. Bader and Gold (2003, p. 12).

82. The general design sketched here would appear to preserve the DB character of the plan, but, depending on the specifics, variations on this structure might raise issues as to whether they would be subject to the defined-benefit or the defined-contribution regulatory regime.

83. Here, as elsewhere in the paper, the description pertains to single-employer plans only. Participants include active employees, employees who have separated from the firm after being vested in the plan but who have not yet begun drawing benefits, and current beneficiaries. 
per year. The premium rate was increased to $\$ 9$ per $\$ 1,000$ in 1991 , and the cap was removed in $1996 .{ }^{84}$ Firms that contributed the FFL amount in the immediately preceding year are exempt from the variable-rate portion of the premium in the current year. ${ }^{85}$

Many analysts have criticized the current structure of premiums as failing to apply economically appropriate prices to the risk that plans actually present to the PBGC. ${ }^{86}$ To be sure, premiums are not completely insensitive to risk under current law; the variable-rate portion of the premium does penalize some underfunding. Even so, the current structure of premiums bears little resemblance to the economically fair structure for two reasons: First, and most obviously, only one risk factor - the level of plan assets relative to plan liabilities-is taken into account in determining the premium, yet the risk confronted by the PBGC also depends on the financial health of plan sponsors and the extent to which plan assets have been invested so as to immunize liability risk. ${ }^{87}$ The second major flaw in the current premium structure is that even the one risk factor recognized is priced only very incompletely. Precise figures are difficult to come by, but one set of calculations suggests that, in 2003, the variable-rate premium was assessed against only about a fifth of current-liability-basis underfunding; the rest was exempted under the FFL-related provision noted above. ${ }^{88}$

Several analysts have argued that, in addition to being too insensitive to risk, the current structure of premiums is simply too low, generating too little revenue given the current scale and structure of risks presented to the PBGC. Steven Boyce and Richard Ippolito simulate a detailed model of the

84. GAO (2003a, p. 9).

85. See, for example, GAO (2005, p. 9, note 24). At first blush it might not be apparent how a firm that has met the standard of the FFL might otherwise be subject to the variablerate premium (which applies, by definition, only to firms with unfunded liability). Such a circumstance can arise because a plan's status with respect to the variable-rate premium is determined using different measures of liability than that used to determine the FFL.

86. Among many others, see VanDerhei (1990), Lewis and Pennacchi (1999), Boyce and Ippolito (2002), and CBO (2005b).

87. See, among others, Lewis and Pennacchi (1999) and Pennacchi and Lewis (1994).

88. Center on Federal Financial Institutions (2005b) stresses the importance of exemptions from the variable-rate premium and states that an even larger fraction- 90 percentof liability was exempted in 2003. Precise figures are difficult to come by, because the variable-rate premium is calculated using its own definition of liability. The estimate quoted in the text is based on the version of current liability used to determine minimum required contributions. This version uses a weighted moving-average interest rate to discount liabilities, whereas the version of current liabilities that is used to compute the variable-rate premium is based on a spot rate. 
DB sector and conclude that a private provider of current-law insurance would demand about twice as much premium income as the current premium structure generates. ${ }^{89}$ VanDerhei concludes that the pricing prevailing as of his writing was even more inadequate: He estimates that levying an actuarially (but not economically) fair risk premium against actual exposure in 1984 would have boosted variable-rate premium income to the PBGC by a factor of about $4 \frac{1}{2 .} .^{90}$ Finally, Christopher Lewis and George Pennacchi, as well as the CBO, estimate that both fixed-rate and variable-rate premiums should be boosted by a factor of about six in order to reflect the full economic cost of current-law coverage. ${ }^{91}$

Although premium revenue clearly seems too low given the current structure of risks presented to the PBGC, it bears emphasizing that premium revenue would not necessarily be substantially greater, and could be substantially less, in a reformed system. Boyce and Ippolito note that if sponsors were bound to a more stringent set of funding rules, and therefore presented less risk exposure to the PBGC, a fully priced set of economic premiums could, in fact, generate much less revenue than is provided in expectation under current law..$^{92}$ The same would be true to an even greater degree with both tighter funding rules and more stringent portfolio investment requirements.

DETERMINATION OF INSURANCE PREMIUMS: PROPOSED REFORMS. The premiums assessed by the PBGC should both allow the insurance program to cover its administrative costs and provide full compensation for all risk presented to it. Plans with sufficient assets, structured to immunize the risk of plan liabilities, present essentially no risk to the PBGC and so should pay no premium beyond the amount required to cover its administrative costs; these can be recovered by means of a successor to the current flat-rate premium. With 44 million insured participants, the PBGC could have covered its administrative expenses of $\$ 263$ million in 2004 with a flat-rate annual premium of about $\$ 6$ per participant. ${ }^{93}$ As many observers have noted, a premium based on number of participants subsidizes plans with older workforces and more-generous benefit provisions at the expense of new plans and plans with younger workforces. To address that concern, a base premium

89. Boyce and Ippolito (2002).

90. VanDerhei (1990).

91. Lewis and Pennacchi (1999); CBO (2005b).

92. Boyce and Ippolito (2002, p. 158).

93. The figure for administrative expenses is from PBGC (2005c). 
could alternatively be tied to insured liability. For example, given the $\$ 1.55$ trillion in PBGC-insured liability in 2002 (the latest year for which data are available), expenses that year of $\$ 222$ million could have been recovered with a charge of about 14 cents per $\$ 1,000$ of insured liability.

Before the design of a risk-based premium can be taken up, two questions of general principle must be addressed: First, should the government merely aim to assess actuarially fair premiums - and therefore only recover expected costs as they would be calculated using the Treasury rate-or should it be required to levy an additional charge to compensate for the fact that its losses occur disproportionately when financial resources are especially valuable? Private insurers acting in the place of the PBGC would demand compensation for such systematic risk, and basic principles of financial economics suggest that the PBGC should do the same. ${ }^{94}$ The reason is not that the government should behave as if it were risk averse itself, but rather that a government seeking to tally the full cost of its programs should recognize that other participants in the economy are risk averse. An implication of that risk aversion on the part of others is that the government should take account not only of the average amount of resources it is appropriating from the private sector but also of the circumstances under which it is doing so. Programs that cause resources to be appropriated disproportionately when times are bad-and hence when resources are especially valuable — should be scored as more costly than programs that appropriate the same amount of resources in expectation but without correlation to the business cycle, and more costly by an even wider margin than programs that appropriate resources disproportionately when times are good.

A logical and appropriate consequence of a charge for market risk is that the PBGC would be expected to run a small surplus on average, once its insurance is fully priced. Pennacchi addresses the same issue in the context of the Federal Deposit Insurance Corporation: "An outcome of setting fair rates is that the FDIC will make profits, on average. That is, premiums less insurance losses must be, on average, positive in order to

94. The assertion here that the PBGC insurance premium should include compensation for risk does not contradict the equivalence, noted in the section on theory above, between Treasury rates and annuity rates in a frictionless, perfectly competitive world in which sponsors are required to fully fund their plans and immunize their risk. If all liability risk has been immunized, as was assumed above, insurance premiums would not reflect a premium for market risk. 
compensate taxpayers for having to fund large net insurance losses during economic downturns." ${ }^{95}$ As Pennacchi notes, the presence of a surplus might incorrectly strike some observers "as evidence of excessive, rather than fair, insurance premiums." As noted by the $\mathrm{CBO},{ }^{96}$ the "problem" of the surplus could be addressed by having the PBGC pay the general fund of the federal government a reinsurance premium, set at the estimated amount that the PBGC has collected from plan sponsors as compensation for risk. Alternatively, if the PBGC comes to be viewed as backed by the full faith and credit of the Treasury, a simpler method for dealing with the expected profit would be to abolish the trust fund and the revolving fund, eliminating the distraction of the balance in those two funds and putting the focus where it should be, namely, on the question of whether premium rates have been set appropriately on a prospective basis. ${ }^{97}$

A second matter of general principle is the question of whether-and to what extent—premiums should be adjusted to the individual characteristics of plan sponsors or reflect only aggregate conditions. Boyce and Ippolito argue that premium rates should reflect only the average probability of bankruptcy across the population of insured entities. ${ }^{98}$ They argue that tuning premium rates to the financial health of individual sponsors would effectively tie premiums to precisely the risk being insured against. Just as an insurance company is not allowed to boost the premium under a term life insurance contract if and when the health of the policyholder has deteriorated, so the PBGC should not be allowed to boost the premium for pension insurance when the creditworthiness of the sponsor has declined. Taken to its logical conclusion, premiums tied to the health of the sponsor could substantially reduce or eliminate the value of the insurance. The BoyceIppolito argument is sensible with respect to the risk factor to which they apply it, namely, bankruptcy risk. However, as was noted earlier, two other factors - the degree of underfunding and the allocation of plan assetsare important as well in determining the overall risk that an individual plan presents to the insurer, and, unlike bankruptcy risk, these factors are unambiguously under the control of the plan sponsor. Failure to adjust

95. Pennacchi (2006, p. 27).

96. CBO (2005b, p. 14).

97. In this case, as discussed more fully below, budget accounting could be performed by recognizing as an outlay the difference between the full economic cost of plan termination insurance and actual premiums paid.

98. Boyce and Ippolito (2002, pp. 140-41). 
premiums to those two risks at the level of the individual plan would unnecessarily continue to give scope for moral hazard to distort the behavior of plan sponsors.

Taking these considerations on board, what could be done to move the system toward rational risk-based pricing of default insurance? Thus far two detailed empirical models of the DB sector have been developed: one described by Boyce and Ippolito and housed at the PBGC, the other described by and housed at the CBO. ${ }^{99}$ Although neither model may be ready to bear such pressure today, both are highly credible, and either might ultimately provide a suitable basis for setting risk-based premiums, especially once the reasons for some important differences between the two models are better understood. ${ }^{100}$ Research, development, and refinement of these models should continue so that either could become a vehicle for setting premiums.

In moving toward market-based premiums, careful thought would have to be given to the design of the transition. Going "cold turkey" to marketbased premiums could force some firms teetering on the brink of bankruptcy, with deeply underfunded plans, over the edge. One way to minimize unnecessary bankruptcies would be to phase in market-based premiums linearly over the same five- or seven-year period allowed for amortization of underfunding: In the first year, assuming a five-year phase-in period, the premium paid would be equal to one-fifth of the market-based premium plus four-fifths of the current-law premium, and so forth. After five years, when sponsors should have eliminated their current underfunding and

99. Boyce and Ippolito (2002); CBO (2005b).

100. The discrepancy that most demands further investigation is the fact that, in the vintage of the PBGC's model described in Boyce and Ippolito (2002), current-law premiums were judged to be too low by a factor of about two, whereas in the vintage of the CBO model described in CBO (2005b), the required scaling factor is estimated to be about six. Some convergence may already have occurred: in its 2004 annual report, the PBGC indicated that the expected claims implied by its model had been revised up from about $\$ 800$ million a year to about $\$ 2$ billion a year. Moreover, some portion of the remaining discrepancy seems to reflect a few readily identifiable differences in underlying assumptions. For example, the $\mathrm{CBO}$ assumes that the plans of all bankrupt firms are terminated, whereas the PBGC assumes that only plans with funding ratios of less than 80 percent are terminated. Also, the CBO model boosts plan liabilities by 20 percent at default, to reflect such considerations as the ability of sponsors to "de-fund" the plan through various means, plus the tendency of retirees at distressed firms to take subsidized early-retirement and lump-sum payments when available. By contrast, the PBGC adjusts liability at termination directly and specifically for the additional drain from subsidized early-retirement and lump-sum payments on a plan-by-plan basis. 
redeployed their assets to immunize the risk of their liabilities, the pricing of insurance would fully compensate taxpayers for the risk they are bearing, which would, at that point, be quite small. Another possibility would be to delay the implementation of risk-based premiums altogether until the end of the first five-year (or seven-year) amortization period.

\section{The Third Locus of Reform: Transparency}

Transparency is considered here with respect to four separate constituencies: workers, financial markets, the PBGC, and taxpayers. Transparency should be improved for each. ${ }^{101}$

REQUIREMENTS FOR DISCLOSURE TO WORKERS: CURRENT LAW. Under current law, "only participants in plans below a certain funding threshold receive annual notices regarding the funding status of their plans, and the information plans must currently provide does not reflect how the plan's assets are invested." ${ }^{102}$ Sponsors are required to report in their annual Form 5500 filing the proportion of plan assets invested in securities issued by the sponsor. However, as the GAO has noted, this information is neither timely nor "readily accessible to participants." 103

101. Yet another possible reform that could be a constructive part of the mix would be to elevate the priority of the PBGC in bankruptcy proceedings. In principle, such a move should cause other creditors to step up the pressure they apply on sponsors to fund their plans prudently. Experience suggests, however, that it would not be a panacea, because clever creditors can devise ways of extracting value from the corporation before the PBGC gets its crack at the remainder. For example, Bodie and Merton (1993, p. 210) describe the case of Republic Steel, which was acquired by LTV in 1984: "Four years before, the plan was underfunded but it had about $\$ 300$ million of assets. A year later senior officers of Republic Steel, some of whom were themselves approaching retirement age, changed the terms of the cash-out option in 1981 so as to make it particularly attractive to take a lump sum in lieu of an annuity. During the subsequent years preceding the merger, retiring employees (of Republic Steel) exercised their cash-out option en masse. When LTV went bankrupt in 1986, the PBGC thus found itself obligated to pay guaranteed benefits on an essentially unfunded plan (\$230 million in liabilities and a trivial $\$ 7,700$ in assets). Despite the obvious effect of the cash-out provision, both the PBGC and the Department of Labor concluded there was no violation of the law." On page 214, Bodie and Merton go on to state more generally, "In the event of financial distress, the interests of subordinated creditors can diverge from those of the PBGC. Debt instruments, such as corporate bonds, often offer creditors ways of withdrawing cash out of a troubled institution before the guarantor can-high-coupon payments, call provisions, sinking funds, and put-option provisions are examples." These observations suggest that a higher priority in bankruptcy could be a useful part of the overall belt-and-suspenders toolkit, but should not be relied upon in isolation.

102. GAO (2003b, p. 17).

103. GAO (2003b, p. 17). 
REQUIREMENTS FOR DISCLOSURE TO WORKERS: PROPOSED REFORMS. Care should be exercised neither to overburden workers with complex and difficult-to-understand financial material, nor to overburden sponsors with onerous compliance requirements. Two pieces of information that should be easy for participants to understand and straightforward for sponsors to prepare are, first, the present value of accrued benefits (useful to the worker in comparing the plan with a defined-contribution plan) and, second, the fraction of accrued benefits that would be funded if the plan were to be terminated immediately. After the initial phase-in period of five or seven years, most sponsors should be in a position to report a funding ratio very close to 100 percent. Exceptions would include sponsors that have granted improvements in plan parameters or increases in shutdown or flat-dollar benefits, and that are contributing the minimum required amounts to amortize the unfunded liabilities generated by those improvements or increases. If plan assets are being used to immunize liability risk, capital gains or losses should not be a source of material deviation from 100 percent funding, although other departures of actual experience from actuarial assumptions could generate deviations from 100 percent funding.

ACCOUNTING REQUIREMENTS: CURRENT FASB REGULATION. As noted above, current accounting requirements allow sponsors to assume a high rate of return on pension assets, commensurate with a heavy allocation of assets to risky assets, but then to smooth the associated volatility in actual returns over five years. In effect, the rules create a form of accounting arbitrage. Coronado and Sharpe show that investors seem to pay more heed to the smoothed figures reported in the body of the financial reports than to the fair market values reported in the footnotes. ${ }^{104}$ Similarly, Franzoni and Marín show that firms with severely underfunded pension plans tend to underperform the overall stock market. ${ }^{105}$ Since 2003 some information about asset allocation has been provided in the footnotes to the financial statements; however, this information is aggregated across all plans sponsored by the firm and provides only a very coarse breakdown of assets, without, for example, any clarity about the duration or quality of fixedincome securities. More recently, FASB has proposed to move within a year to requiring that fair-market-value measures of assets and liabilities be reported on the balance sheet, and to reconsider the appropriate treat-

104. Coronado and Sharpe (2003).

105. Franzoni and Marín (2006). 
ment of pension expense in the income statement over the next two to three years. ${ }^{106}$

ACCOUNTING REQUIREMENTS: PROPOSED REFORMS. The general thrust of today's financial accounting requirements, which feature accrual-based concepts and allow firms to report a net pension expense (accrued expenses less returns on assets), is sensible and economically appropriate. Within that framework, however, two crucial adjustments would improve the value and transparency of financial information greatly, namely, building the calculation of all items around fair market values rather than allowing delayed recognition of changes in assets and liabilities, and using the ABO concept throughout. If firms deployed their pension assets so as to immunize their interest rate risk, if demographic factors such as tenure and mortality played out as expected, and if plan parameters were not changed, net pension expense each period would equal benefits accruing during the period, regardless of rates of return on financial assets or changes in the shape or level of the term structure of interest. Information about asset allocation should be released on a timely basis and at the level of the individual plan, and should include greater detail about the quality and duration of fixedincome securities held by each plan.

DISCLOSURE TO THE PBGC: CURRENT LAW. Firms are required in their annual Form 5500 filings to provide some information about their liabilities and assets, but that filing need not take place until $9 \frac{1}{2}$ months after the close of the plan year. On that form the estimate of plan liabilities is as of the beginning of the plan year; therefore by the time the PBGC receives the information it is almost two years old. Asset data on Schedule H of the form are as of both the beginning and the end of the plan year, which means that information about the holdings of the plan is nearly one year out of date by the time the $\mathrm{PBGC}$ receives it. Moreover, the information on the form does not, as a practical matter, allow the PBGC to parse the assets held in pools, trusts, and mutual funds into their fundamental components (that is, specific forms of bonds, equities, and so forth).

DISCLOSURE TO THE PBGC: PROPOSED REFORMS. To allow it to effectively monitor and enforce the asset allocation requirements proposed here, the PBGC would need synchronous information on assets and liabilities on a far timelier basis than occurs under current law. The information provided under current FASB requirements would not be sufficient, because the 
PBGC would need data at the level of the individual plan as well as more detail on the characteristics of the assets in each plan, including information on the quality and duration of bonds.

BUDGETARY TREATMENT OF THE PBGC: CURRENT LAW. Revenue to the federal government from the PBGC is currently defined to include premium income as well as the investment income of the revolving fund (the receptacle of premium income and immediate source of benefit payments) but not the investment income of the trust fund (the receptacle of assets taken over from sponsors of terminated plans). Outlays are defined to include the portion of benefit payments and administrative expenses deemed not covered by assets assumed by the PBGC. Thus the net long-term obligation assumed by the PBGC upon termination of a plan is reflected in the budget only over time, not at the moment of termination, much less before then, as the fortunes of insured plans deteriorate. A consequence of the current treatment is that the PBGC has been shown as having reduced the unified federal deficit by billions of dollars thus far, despite having accumulated a substantially negative net worth.

BUDGETARY TREATMENT OF THE PBGC: PROPOSED REFORMS. One way to improve the budgetary treatment of the PBGC would be to score the economic subsidy delivered through the PBGC as an outlay. The subsidy could be calculated as the difference between the full economic cost of plan termination insurance and actual premiums paid. ${ }^{107}$ Scoring the PBGC in this manner would, in effect, extend the reach of the Credit Reform Act to insurance programs; currently the methods prescribed under that act are applied only to loans and loan guarantee programs. ${ }^{108}$

107. CBO (2005c, p. 9) describes an approach along these lines.

108. The approach recommended here would treat the federal government as liable for all obligations taken on by the PBGC, despite the fact that, under current law, the PBGC is not backed by the full faith and credit of the Treasury and therefore is liable only for obligations that it can pay out of current-law resources. (CBO, 2005d, p. 5, notes this issue.) Thus, under this budgetary treatment, legislation to back the PBGC with the full faith and credit of the Treasury would be scored as having zero budgetary cost. Unattractive as that consequence is, however, the alternative may be worse. For example, if, under an accrual-type method, PBGC-related spending authority were interpreted as strictly limited to amounts that could be financed out of current-law resources, then all further plan terminations would be scored as having zero budget implications over the long term (additional outlays in the near term would be offset by reduced outlays in the longer term once the PBGC's currentlaw resources have been exhausted), because the PBGC is already projected to become insolvent. 


\section{Looking Ahead: Must the Government Remain the Provider of Pension Insurance Forever?}

Most pension analysts agree that the government should play some role in enhancing the security of retirement income derived from DB plans. ${ }^{109}$ The argument for government intervention in some form derives in part from suspicions that neither workers nor financial market participants would be sufficiently well informed or sophisticated about pension finances to provide effective market discipline in a fully deregulated environment. It derives as well from doubts about whether workers would be well positioned to bear the risk associated with uninsured pension promises, and from concerns that workers and firms might expose themselves to more risk on the assumption that society would provide some form of financial backstop to DB participants even in the absence of a formal insurance program.

Some analysts, while agreeing that some form of government intervention is warranted, have argued that the current form of intervention, in which the government acts as the provider of plan termination insurance, is not the most appropriate one. For example, Bodie has stated that "economic reasoning establishes a rationale for insuring defined-benefit pensions against the risk that the plan sponsor will default on its promise to provide benefits. It does not establish a rationale for the government to provide such insurance. The federal government is probably not in the best position to carry out such a task [emphasis in the original]." 110 In the vision put forward by Bodie and others, the government would continue to mandate that sponsors obtain plan termination insurance, but government itself would not provide that insurance; instead it would be provided by private insurers.

109. One of the few analysts who leaves his views ambiguous in this regard is Pesando (1996, pp. 286-88). He notes that if workers were well informed and financially sophisticated, government might not need to intervene at all, because workers would discount the value of promised future pension benefits to an appropriate extent in light of the financial health of the sponsor and the funding condition of the plan, and would adjust their demands with respect to current wages accordingly. Through a process of self-selection, workers could also sort themselves across firms, with the more risk-averse workers choosing to work for more financially sound firms with better-funded pension plans.

110. Bodie (1996, p. 20). 
In part, the case for private provision rests on the view that it would reinforce the full risk-based pricing of plan termination insurance. ${ }^{111}$ Left unfettered, private insurers could take into account the risk factors that are largely or completely ignored under the structure of insurance premiums allowed under current law. Sponsors would face the full economic consequences of their actions with respect to their plans, and so would be motivated to take on only the economically appropriate amount of risk in those plans. In return, private insurers could provide coverage of all promised benefits—-not just those falling beneath an arbitrarily determined cap-and healthy plan sponsors could be assured of not having to subsidize the coverage provided to their shakier counterparts.

One way to introduce a system based on private provision would be to implement the reforms outlined in the preceding section. After those reforms have been fully phased in and any transition period has passed, the risks presented to any insurer-government or private-should have been vastly reduced. Boyce and Ippolito note, for example, that the scale and dispersion of risks under a reformed regulatory structure would much more closely resemble other forms of coverage currently provided by private insurers. ${ }^{12}$ At that point, if the system were functioning as intended, a switchover to private provision could be implemented with little or no discontinuity.

Some analysts have recommended an even more aggressive approach, in which private provision would be a first step in the reform process rather than a last step. For example, Carolyn Weaver has argued that "the government should simply surrender its position as monopoly supplier of pension insurance and shift the insurance (or guarantee) function to the private sector." 113 One prominent exponent of an aggressive approach has been Richard Ippolito, who was serving as chief economist of the PBGC when his 1987 article propounding this point of view was published and who

111. This approach would put insurance companies, rather than workers or shareholders, in the position of enforcing market discipline and thus provides a plausible answer to the observation that workers and even equity investors seem to have considerable difficulty accurately processing information about DB plans.

112. Boyce and Ippolito (2002).

113. Weaver (1997, p. 156). Weaver (1997, note 100) cites Pesando (1982), Sharpe (1976), and Smalhout (1993) as also supporting private provision of plan termination insurance, or "risk-based premiums brought about (in whole or in part) though private supply." 
has reiterated that view more recently. ${ }^{114} \mathrm{An}$ important impediment to implementing an aggressive approach would be the need to design a prudent transition. Indeed, even proponents of an aggressive approach might end up adopting a reform program along the lines sketched in the preceding section as a bridge to their preferred outcome.

Support for private provision of plan termination insurance is hardly universal. Some who have taken the opposing point of view have argued that the PBGC as currently constituted provides an important form of social insurance, cushioning workers and firms from adverse economic developments. Moreover, in providing such cushioning, the PBGC encourages both workers and firms to be open to the risks inherent in a fluid, dynamic economy such as ours. Far from promoting economic efficiency, a move to limit the ability of the PBGC to provide social insurance would, in the view of these analysts, risk a backlash that could result in much more damaging constraints being placed on the economy. In the words of Dallas Salisbury, "Agree or not, Congress intended a social insurance modelthat is, explicit subsidy within the defined benefit system." 115 Salisbury goes on to say, "The program was legislatively established with social insurance goals. A move to the casualty insurance model may well be justified, but it carries with it a fundamental change of mission. Too many analysts fail to begin their work with an articulation of why Congress was wrong and why they should change the mission. Instead, they analyze the program against a casualty model and declare the program in need of reform. By so doing, they confuse rather than enlighten. ... The present mission is

114. Ippolito (1987, p. 22) wrote as follows: "Implementation of any one of these policies [charging economically fair premiums, boosting the standing of the PBGC in bankruptcy proceedings, and so forth] would substantially reduce the inefficiencies in the pension insurance system. The problem generally is that these solutions would take a long time to become fully effective. Another approach would be to simply eliminate the PBGC, while retaining a sufficient portion of expected transfers to make the change politically feasible. This could be done by requiring termination of pension plans as of some announced date as a condition for PBGC coverage. Pension promises outstanding at the time of termination would be vested in nominal terms and guaranteed by the PBGC, as under present law, while new pension promises, including indexation of terminated benefits to future wages, would accrue under the new pension plans. All continuing plans either would be exempt from insurance coverage or would be required to purchase insurance at market rates in the private sector."

115. Salisbury (1996, p. 313). 
social insurance. Against that mission the PBGC has been a very successful agency." 116

Leaving aside the normative question of whether the PBGC should have a social insurance role as part of its mission, it is worth noting that the insurance-related characteristics of the overall DB system arguably would not be altered greatly under the approach suggested here. Under that approach, employees of distressed firms could be paid virtually all their accrued benefits, and a firm experiencing financial distress would still be able-as under current law-to lighten its financial load by shedding pension-related expenses, although under the proposed approach it would do so by terminating a fully funded plan rather than by causing a deeply underfunded plan to become a public obligation. A system designed along these lines would not involve any announcement that substantial new resources have been directed toward the employees of a certain failing firm, for the simple reason that a funding gap would never have been allowed to emerge.

\section{Conclusion}

The reform program proposed in this paper addresses each of the shortcomings of the current system identified in the introduction. Whereas the current system exposes some workers to financial risks that they seem ill prepared to hedge, the reformed system would render the pension promise essentially free of risk. Similarly, whereas the current system creates scope for moral hazard by tolerating gross mispricing of insurance and misleading reporting of pension activity in firms' financial statements, the reformed system would ensure that taxpayers are fully and fairly compensated for the risk they bear and that investors are provided with transparent, market-

116. Salisbury (1996, pp. 315-16). Weaver (1997, p. 154), among others, disagrees strenuously that the PBGC should aim to play any social insurance role: "Mixed insurance-transfer programs-euphemistically referred to as 'social insurance' by proponents-inevitably distort the allocation of resources in the economy and are notoriously poor at targeting scarce resources. In PBGC's case, the system subsidizes wages in failing firms, artificially prolonging the life of inefficient firms at the expense of efficient ones; encourages firms with a greater likelihood of failure to offer compensation in the form of unfunded pension promises the PBGC will likely pay; and, by weakening unions' stake in the long-term viability of firms, makes capital investment in these firms less attractive." 
value-based information about pension assets and liabilities. The much greater transparency of a system founded on certainty and clarity should also substantially improve the accuracy with which asset prices reflect available information about DB pension plans. Under the reformed system, the government-sponsored insurance program would stop providing subsidized insurance coverage, and healthy sponsors would be substantially free of the risk of having to subsidize the risky pension promises of firms with risky pension portfolios and low funding ratios. Finally, the plan proposed here would greatly reduce the complexity that suffuses nearly every aspect of the regulations now governing DB plans.

The payoff to a successful reform could be substantial. Workers could be guaranteed the full amount of their promised benefits rather than an arbitrarily capped amount. Taxpayers could be relieved of the threat of significant further growth in an already-considerable contingent liability. Sponsors could operate within a system that is far more transparent and imposes lower costs of compliance, and the financially healthy firms among them could be freed of the risk of having to subsidize their shakier counterparts. In that event, workers and firms could evaluate the pros and cons of DB plans on their economic merits and decide whether-and to what extent- the DB promise should be part of the preferred overall compensation package. 


\section{Comments and Discussion}

Jeffrey R. Brown: David Wilcox's paper on the Pension Benefit Guaranty Corporation and its reform is a pleasure to read. Despite the enormous complexity of the topic, this paper provides a thorough, careful, and clear description of the many problems that are deeply embedded in the structure of the nation's defined-benefit pension system.

In addition to describing the problems with great clarity, Wilcox takes the bold next step of making normative policy recommendations about how to reform the system. To the many interest groups that have a direct financial stake in the future of the PBGC, these policy recommendations will be seen as provocative, both relative to the status quo and relative to the reforms that will likely be enacted. Indeed, as an economist with a strong preference for market-based solutions, I must confess that my own initial reaction to the paper (based on an initial, cursory read) was that the proposals seemed heavy handed: they mandate solutions for nearly every aspect of pension plan funding, including in which assets a plan may choose to invest.

After reading the paper carefully, however, I realized that these proposals follow perfectly from the analysis. Indeed, it is hard to argue with them at all if one accepts Wilcox's three axioms plus one further condition. The three axioms that Wilcox identifies are that workers should be able to view their DB pension as risk-free, that taxpayers should be fully compensated for any risk they bear, and that low-risk sponsors should not have to subsidize high-risk sponsors. Anyone who rejects any of these axioms will also likely have a different view about the appropriate policy response.

The additional condition, which these proposals implicitly assume, is that reform efforts should be focused on making the PBGC work, as opposed to scrapping it completely and replacing it with something altogether different 
(such as mandatory private DB insurance). Given that this is a politically realistic condition, at least in the short run, the Wilcox proposals may be viewed as a good standard against which other reform proposals should be evaluated. Although Wilcox does briefly mention the idea of private insurance as a possible last step in the reform process, a case can be made that it should be the first and possibly the only step.

The natural starting point for any economist thinking about government intervention is to ask, "What is the market failure that the PBGC was designed to address?" After all, if consumers were fully rational, forward looking, and well informed, there would be very little need for government intervention. Firms and workers would negotiate an optimal compensation contract, and firms that credibly committed to a less risky DB promise would be able to provide lower compensation than would firms with a riskier promise. Barring market failure, the equilibrium outcome would be efficient.

The market failure here seems to be that the average worker is not fully rational, forward looking, and well informed. Given the increasing body of evidence suggesting that average workers have a low level of financial literacy, ${ }^{1}$ and that they make optimization mistakes even in much simpler contexts, ${ }^{2}$ it is reasonable to think that the average worker is unable to fully process the information required to assess the risk of his or her pension plan. Indeed, given how complex the required calculations are, it is probably unreasonable to think that anyone outside of a small subset of experts could make an appropriate assessment of the risk of a given DB plan. After all, it is not enough to know the net present value of plan assets and liabilities. One must also know about the stochastic properties of both the assets and the liabilities, the future funding behavior of the plan sponsor, the distribution of plan sponsor insolvency risk, and how these factors are correlated with the individual's marginal utility of income in future states of the world.

Of course, even if one accepts that most workers have inadequate information or suffer from bounded rationality, it does not necessarily follow that the solution is for the government to insure private DB plans. There are other, less intrusive steps that could provide DB participants with pension security while simultaneously providing market discipline to ensure that firms have appropriate incentives to fund their plans. One limited approach would be to combine stronger and more uniform disclosure rules

1. See, for example, John Hancock Financial Services (2002).

2. See, for example, Choi, Laibson, and Madrian (2005). 
with stronger protections for accrued pension benefits as part of bankruptcy proceedings. The logic is that long-term pension promises are a form of debt for the employer. If this debt were given seniority over the employer's other liabilities-including those to its bondholders-in bankruptcy proceedings, pension participants would have at least some limited amount of protection in the event of the employer's bankruptcy. Bondholders, including sophisticated institutional investors, would also have the incentive to ensure that pension promises are fully funded, so as to avoid having that funding risk imposed on them; for example, they could require as part of their debt covenants that the employer purchase private insurance for its DB pension plan.

Of course, such an approach does not make the pension promise risk free. According to one study, ${ }^{3}$ from 1981 to 2000 the average default recovery rate from senior secured bonds of all ratings was approximately 54 percent. Even if pension promises could typically be recovered at a higher rate, they would still impose risk on participants. In addition, a voluntary market for pension insurance might suffer failures of its own, such as from asymmetric information. Moreover, the experience of Republic Steel, described in a study by Zvi Bodie and Robert Merton cited by Wilcox, ${ }^{4}$ suggests that elevating the status of the PBGC in bankruptcy proceedings might not be sufficient in itself given the cleverness of plan sponsors in devising ways to strip assets from the pension fund.

A somewhat more intrusive step would be for the federal government to mandate private DB insurance coverage; this would force all plans into the pension insurance market and thus avoid adverse selection. Private insurers would then play the role of imposing appropriate funding discipline. Insurers would set premiums to reflect the degree of risk, and plan sponsors would then have appropriate incentives to choose an optimal funding and asset allocation strategy. To avoid problems of asymmetric information, employers would have to be compelled to provide insurers with all necessary information about plan assets and liabilities, and insurers would be permitted to price premiums differently according to risk.

This, however, was not the path chosen by Congress in 1974. Instead the government chose to be the direct provider of the insurance itself. It is not clear that this was the best decision, nor is it clear that Congress could

3. Hamilton, Gupton, and Berhault (2001).

4. Bodie and Merton (1993). 
not unwind the existing system and adopt mandatory private insurance if the political will existed to do so. The recent debates over PBGC reform, however, suggest that this is politically unrealistic, at least in the short run. Initial conditions matter in politics as well as in economics, and given the interests of current players, it seems implausible that the PBGC system will be abandoned anytime soon. Given this situation, Wilcox wisely concentrates on a more focused set of questions, namely,

-What is the state of health of the DB pension system in the United States today?

- How well is the PBGC performing its job now?

-What reforms would make it better?

With regard to the first question, it is well known that the DB system is in significant distress, and the paper does a thorough job of documenting this. What is less understood by the public, but expertly explained in the paper, is why the plans are in trouble in the first place. To read the popular press and industry trade publications, it would appear that the main problem is the "perfect storm" that coalesced in the early 2000s: falling interest rates increased the present value of pension plan liabilities at the same time that falling equity prices shrank the asset base for most DB pensions. As a result, the ratio of plan assets to plan liabilities dropped substantially over a few years.

This explanation is unsatisfying, for at least two reasons. First, many DB pension plans were experiencing funding problems before the perfect storm appeared. To be sure, declining interest rates and stock prices made the problem much worse, but they did not create it. Second, because asset price fluctuations are an everyday occurrence, the more important question is why firms chose to expose themselves to this risk in the first place. Although possible explanations abound for why firms fail to insulate themselves from pension funding risk, Wilcox's paper can be interpreted as pointing to the PBGC itself as a leading candidate.

The intent of the lawmakers who created the PBGC was to reduce risk. Established as part of the Employee Retirement Income Security Act in 1974, the PBGC was designed to enforce pension funding requirements to ensure that plan sponsors set aside sufficient assets to meet their future liabilities. In addition, the PBGC serves as a DB insurer, guaranteeing that retirees will receive their retirement benefits (up to a specified maximum) even in the event that the plan sponsor goes bankrupt with an unfunded pension plan. 
In practice, however, it is not clear that overall risk has been reduced. Wilcox divides the many problems with the structure of the existing system into three broad categories. The first set of problems is that current funding rules are inadequate. For example, firms are required to fund only 90 percent of their pension liability, they are not required to use riskless discount rates despite the fact that the liabilities are relatively certain, they can use various smoothing and amortization methods to alter their annual contributions, and more. The net effect is that firms can claim to be fully funded even though their true termination liability vastly exceeds their available assets.

A second category of problems is the nearly complete lack of risk adjustment. The standard PBGC premium is based on the number of employees covered by the plan. There is no consideration of benefit generosity, the firm's credit quality, the risk-return characteristics of the plan portfolio, or the degree of mismatch between the plan's assets and the firm's liability structure in different states of the world. In the extreme, a plan that chose to invest 100 percent of its assets in an emerging markets stock fund would face no higher premium than one that chose to invest 100 percent in nominal bonds with durations that exactly match its liabilities. The PBGC variablerate premium, which is essentially a fixed-rate fee applied to the amount of underfunding, also ignores most of the relevant risk factors.

The third category of problems is that the information disclosure required under current law is inadequate and confusing. Funding information, such as that filed on Form 5500, is provided with a long lag, and even then not in a format that participants can easily digest. Furthermore, the rules governing the liability concept used, the discount rate, and the use of smoothing mechanisms differ across the PBGC, the Treasury, and financial accounting standards.

Wilcox's proposed reforms are designed to tackle all three of these problems. On the funding front, he would require that the accumulated benefit obligation (his preferred measure of plan liability) be calculated using something approximating a risk-free term structure, which would clearly be an improvement over current law given that the accrued liabilities are relatively riskless (except for demographic risk). Firms would be required to hold allbond portfolios with durations that matched that of the liabilities. Other useful provisions would eliminate the gaming that occurs when firms are permitted to provide new benefits when the plan is underfunded.

To better align incentives, the Wilcox reform suggests moving to riskbased premiums. I wholeheartedly endorse this concept: indeed, if the gov- 
ernment would only charge market prices for PBGC insurance, many of the other funding restrictions would prove redundant. Nonetheless, I am highly skeptical that the government is capable of implementing this approach. As Joseph Stiglitz has pointed out, ${ }^{5}$ the government "faces a tremendous disadvantage in assessing risks and charging premiums based on risk differences." Attempts to differentiate among firms, industries, or regions based on risk characteristics would lead to political maneuvering, as, for example, senators from Michigan seek to protect Detroit automakers. Furthermore, as George Pennacchi has noted in the context of deposit insurance, ${ }^{6}$ were the government to charge the correct market premium, it would earn accounting profits on average, because it is being fully compensated for risk. Such an approach is unlikely to be politically sustainable.

Although I am inclined to believe that a government-mandated, but privately provided, DB pension insurance system would be preferable to the Wilcox reforms. I also believe that, conditional on having a governmentadministered pension insurance system, the Wilcox reforms are eminently sensible. They are designed to reduce DB participant risk, limit taxpayer exposure, and properly align firm incentives.

Before fully embracing the Wilcox reforms, however, it is worth considering one possible consequence that Wilcox himself appears to dismiss a bit too quickly. Because these reforms would rationalize the pension funding process, firms would lose the government subsidy they implicitly receive today. As a result, these reforms would likely hasten the shift from a DB to a DC (defined-contribution) system. For many reasons, this may be the efficient outcome.

But if it is indeed true that individual workers lack the training, financial acumen, and foresight to make perfect financial decisions-which, after all, appears to be the primary rationale for having a PBGC in the first placethen it should be noted that most $401(\mathrm{k})$ plans are not yet optimally designed to account for workers' lack of financial sophistication. Although there is a growing movement toward designing 401(k) plans so as to make them suitable even for such unsophisticated investors, a number of hurdles remain. For example, approximately three-quarters of 401(k) plans do not even offer participants an option to take their withdrawals in the form of a lifetime annuity; this omission may leave many retirees inefficiently exposed to

5. Stiglitz (1993, p. 114).

6. Pennacchi (2006). 
longevity risk. ${ }^{7}$ In such a second-best world, where the alternative to a poorly designed DB system is itself not adequately designed, one cannot be absolutely certain that reforming the PBGC to remove the implicit subsidy will necessarily lead to better overall retirement security.

In that case, although enactment of any reforms resembling the Wilcox proposals would be an important positive step, policymakers should not be content with just "fixing the PBGC." They should also reform the DC system to ensure that it provides a secure source of retirement income for all workers. And if and when policymakers are prepared to make such changes, I hope to read another David Wilcox paper on how it should be done.

Douglas Holtz-Eakin: David Wilcox has delivered an outstanding paper, and a very timely one. The Financial Accounting Standards Board has just issued its proposed revisions to accounting for pension plans, and the HouseSenate conference committee is moving toward a final version of pension reform legislation even as I write these remarks.

Certainly there is a problem with the status quo. A quick survey of the defined-benefit pension world reveals a lot of underfunding by sponsorson the order of $\$ 450$ billion for single-employer plans alone. In addition, the federal guarantor, the Pension Benefit Guaranty Corporation, is deep under water in any economic sense. Yet nobody broke the law. So we have a problem.

The caveat to this assertion, of course, is that maybe workers are engaged in some very sophisticated hedges that we cannot observe and so are immunized to this problem, but I don't think so. For that reason I concur with Wilcox that the pension promise should be riskless. To my eye, pension benefits are compensation earned at one point in time but paid at a later one. The public policy goal is to build a very secure bridge through time for this compensation so that the workers actually receive it.

Before turning to Wilcox's approach to doing so, let me note that making pensions riskless to the workers means that some other group or entity has to bear the risk. If it ends up being the taxpayers, then I again concur with Wilcox that another policy objective should be to ensure that they are compensated for their exposure to risk. During my tenure at the Congressional Budget Office, we undertook a number of efforts to present to the Congress the budgetary consequences of recognizing market risk in financial transactions involving the government: in the PBGC (using formal financial

7. See, for example, Brown and Warshawsky (2004). 
models), in Social Security reform involving individual accounts (using stochastic simulations), in the Federal Housing Administration, in student loan guarantees, in the America West Airlines loan guarantee, and in deposit insurance. One lesson that I learned was that financial risk is a very abstract consideration to most members of Congress. Indeed, even among economists there is far from a consensus on how best to proceed. The combination is even more daunting: confused congresspeople turn to professional experts and receive conflicting guidance. Introducing budgetary recognition of market risk will be a hard sell.

But taking full account of risk is very important on a prospective basis, because there is already a large legacy overhang of unfunded pension guarantees. I agree with Wilcox that the taxpayer is likely going to end up picking up the tab for this legacy. It would be desirable to minimize the potential of repeating this experience in the future.

Let me now focus my comments on three areas: exposition, reforms, and politics. First, I commend David Wilcox for an expositional tour de force. Two aspects of the paper in particular-the sterling "crash course" in DB pensions and the anatomy of a plan failure-are first-rate pieces of exposition. I think the latter is especially important because there has been a lot of talk in recent years that the current distress in the pension system is the result of a "perfect storm": an unusual coincidence of interest rates falling just as stock prices were also going down. The reality is that the situation does not stem from a perfect storm, and that in the absence of policy changes these failures will recur, because plans are not fully funded and pension insurance is badly underpriced.

Next, consider the reforms that Wilcox proposes. The heart of the paper is the combination of theory and proposed reforms. Wilcox makes a convincing case that the goal should be to compute liability (defined as the accumulated benefit obligation) using a yield curve approach, quickly amortize any underfunding regardless of its source, and invest pension assets in bonds that match the maturity structure of the liability. What kind of reforms would yield this outcome? Wilcox groups them into three areas.

The first area (or locus, to use Wilcox's term) comprises funding requirements, limitations on benefit increases, and portfolio investment restrictions. Wilcox proposes that "To minimize the risk presented to workers, taxpayers, and healthy sponsors ... sponsors should be required to fund benefit accruals each year plus amortize any shortfalls or surpluses over a reasonably short period, all on a mark-to-market basis." 
I think the reforms proposed in this area are eminently sensible. It is especially important that assets and liabilities be marked to market, that all sources of underfunding be treated equally, and that real resources be used to offset any underfunding. A large part of the problem to date has been the divergence between the accounting of pension plans and their actual economic status; this strategy ensures their alignment.

The second area involves the pricing of PBGC insurance. PBGC insurance is too cheap on average and is not priced to reflect the risks imposed on the taxpayer. ${ }^{1}$ Wilcox proposes revamping the system to address this shortcoming. Here there are three issues. First, it makes sense to cover administrative expenses with a base premium scaled to each plan sponsor's insured liability.

Second, insurance should be priced to compensate for plan-specific risk. As Wilcox points out, if the rest of his proposed reforms are also implemented, then plans that are fully funded and that have invested so as to hedge the risk of plan liabilities will expose the PBGC to no risk and should pay no additional premium. All others should.

Developing firm-specific risk measures is a Herculean undertaking. The Congressional Budget Office's analysis of adding a risk-based element to the current premiums identified two roughly comparable approaches: tying the premium to the creditworthiness of the sponsor, and tying it to the fraction of plan assets held in risky equities. If Wilcox's other reforms work as proposed, the latter will not be an issue. Instead the only risk is that underfunding will not be eliminated, and this is presumably captured by tying the premium to the sponsor's credit rating.

The final issue is whether premiums should cover market risk. Every other financial market participant demands compensation for systematic risk, but the federal government ignores the cost of such risk in evaluating its programs. The practical implication of incorporating market risk into the PBGC's premiums, as Wilcox points out (borrowing from George Pennacchi), is that the insurance program would not break even on aver-

1. In principle, taxpayers face no risk from PBGC shortfalls. Benefit guarantees are to be paid out of accumulated premiums and the assets of failed plans. If these are insufficient, beneficiaries would receive reduced pensions. As Wilcox notes, the law governing the PBGC explicitly does not oblige the U.S. government to be the pension provider of last resort. In practice, however, it is universally agreed that Congress would step in and provide new funding before pensions were cut. 
age but instead would build a surplus. This is entirely sensible, but again it will be a hard sell to members of Congress who might view an everaccumulating PBGC net worth as evidence that its insurance has been overpriced.

With regard to transparency, I believe Wilcox has it right on the mark: more transparency is a key to lasting reform. And I cannot help but endorse changing the current budgetary treatment of the PBGC, which yields nothing but confusion and poor budgetary incentives.

Finally, are Wilcox's proposals robust to the politics of pension reform? As I mentioned above, the Congress is now working toward comprehensive pension reform, and so one might think that these proposals should be an element of the debate. Unfortunately, they are dead on arrival.

That is a shame, because pension reform is an infrequent event and it would be nice to get it right. Moreover, all of the key elements that Wilcox addresses-yield curve approaches to liability, risk-based premiums, portfolio restrictions, transparency - are part of the debate. But his approach runs counter to the legislative tide in three ways.

First, the reforms he proposes are an interlocking, comprehensive whole. Risk-based premiums are made easy because underfunding should be greatly reduced and portfolios restructured to hedge the key risks. Transparency is enhanced by focusing on a single measure of liability and eliminating accounting gimmicks such as credit balances. And so forth. In short, Wilcox has served up a choice, well-trimmed piece of policy steak. But the legislative process prefers sausage.

Second, too many pension reform participants want more risk and more time. Plan sponsors want to gamble on equity appreciation to make up their current underfunding, and legislators want to give them more time to get their house in order. In my view, neither impulse is correct, but both are important elements of the political landscape, and Wilcox's proposals run directly against them.

Finally, Wilcox's reforms are one-size-fits-all, and they should be. But a quick reading of the pension reforms that have passed the House and Senate reveals myriad special and targeted provisions-the most egregious being the two decades given to airlines to make up underfunding.

In short, these reforms are simply not going to go directly from the Brookings panel to Congress' ear. But Wilcox has served the policy process well by providing a clear exposition of the problem, a coherent, internally consistent set of objectives, and a roadmap to real pension reform. 
General discussion: Henry Aaron objected to Wilcox's first axiom, that workers should be able to view the promise of a DB pension as free of risk. He noted that in the Social Security debate it had become obvious that, despite all attempts to diversify risk, the system will never be entirely riskless. Richard Cooper went further, arguing that uncertainty is part of life and that people over a certain age should be expected to think ahead and protect themselves.

Edmund Phelps discussed the connections between DB plans and innovation by firms. Innovations expose employees to additional uncertainty about their jobs, which they may be happy to bear since it may be advantageous for their jobs. But DB plans expose them to the additional uncertainty that comes with bankruptcy if the innovation is not fruitful and benefit guarantees are incomplete. He saw a second connection through the effect that such failures have on the incentives for future innovations. Since benefit guarantees are costly, past failures raise the costs that potentially innovative firms must bear in the future. More generally, Phelps noted that if innovations add to uncertainty, sparing one stakeholder from risk must necessarily raise the risk faced by others.

Several panelists discussed the usefulness of DB plans and the implications of their decline. Gary Burtless observed that the DB plan is a strange addition to the labor compensation package in that, under most plans, a worker's accrual of financial claims is astoundingly nonlinear over the terms of her service. Benefit accruals are part of compensation. If the employee works for the required number of years and attains the age requirement of the plan, she enjoys substantial benefits. But if she leaves her job before then, either voluntarily or involuntarily, the benefits she receives are sharply lower than the accrued value of compensation already contributed. And if she keeps working after meeting the age and service requirements for drawing a pension, she receives a sharply lower compensation rate. Burtless raised the question of why the government and disinterested taxpayers should insure DB plans with such features. One reason, he noted, is that the PBGC is expected to provide useful financial regulation, helping investors understand the liabilities their company faces and helping workers understand the risks entailed in their compensation package. But he noted that most workers fail to understand that their greatest risk is of an interruption in their service before they meet the age and service requirements for full benefits.

Burtless agreed that many of the changes suggested by Wilcox would be useful in the long run, but also that the thorough overhaul he proposed 
would be politically difficult to achieve. For the short run he suggested a simple improvement to current rules: the PBGC should not insure additional pension credits for firms whose pension funds are underfunded by more than a certain percentage. He reasoned that this would be less politically controversial than many of the other proposals.

Alan Blinder suggested that Burtless' criticisms of present plans do not apply to the general concept of DB plans, but only to some peculiar features of them that have become the norm. He reminded the panel that Social Security benefits do not have the nonlinear accrual feature of most private DB plans. An important question is whether to try to fix the troublesome features of DB plans, which have been favored as a way to relieve workers of investment risk. If the answer is no, Blinder reasoned, this would be a further argument for preserving the DB nature of Social Security and possibly for making Social Security's share in the typical employee's retirement package larger rather than smaller. He, too, agreed that the wholesale changes for reforming DB plans suggested by Wilcox were politically unlikely to be adopted, but he reasoned that mandating private insurance for DB plans deserved consideration once a solution to the large, immediate problems of the PBGC had been addressed.

Cooper declared himself sympathetic to Blinder's suggestion about strengthening the retirement safety net but noted that this could be done with an alternative system, one that had at its core a defined-contribution plan but also provided social insurance should an individual's retirement income fall below a certain threshold. If such insurance could be provided, he favored pushing the entire pension system toward defined-contribution plans. Cooper also observed that other parts of the nation's retirement system shared the strange benefit accrual features that Burtless had described for DB pensions. The military pension system provides no vesting for up to twenty years of service and then vests 100 percent. He claimed that such a system is unsustainable in today's world and has to be changed.

Benjamin Friedman considered how the demise of the DB pension system might affect workers' ability to annuitize their non-Social Security wealth. He noted that although many private group plans do provide useful annuities, the market for individual annuities does not function well because of adverse selection. If DB plans were largely to disappear, he argued, public policy should devise a way to make such group annuities available to all employees. Robert Gordon agreed that the analysis of DB plans should be viewed in the broader context of other retirement and insurance 
programs. As with proposals to privatize Social Security, the transition away from DB plans would be a major problem involving costs that someone would have to bear.

Friedman also addressed the issue of legacy costs. He reasoned that these costs are simply deferred payments for labor services, and economists should be among the first to point out that they are not conceptually different from delayed payments for capital services. Anyone who thinks that a firm in bankruptcy or even approaching bankruptcy should be obligated to its debtors but relieved of its pension obligations is missing the point that these are parallel obligations, and firms ought to be held responsible for them in parallel fashion. George Perry remarked that no firm could have predicted thirty years ago that their health care obligations would be as high as they are today. Friedman agreed that the health care portion of the cost is exceptionally large, but firms should be aware that they are exposing themselves to macroeconomic risk. If a firm financed a plant by issuing a noncallable bond, no one would support relieving the firm of its obligations to the bondholders if interest rates fell. Gordon observed that both obligations can be eliminated by bankruptcy. The question is whether the federal government has any role in insuring individual pensioners in a different way than bondholders. James Duesenberry noted that pension design should recognize the fact that extreme, unforeseeable changes cannot be dealt with by diversification and insurance. The current problems with DB plans are concentrated in firms that in the 1950s and 1960s were large oligopolies, with strong unions and without foreign competition. It was arguably impossible that they could have insured against the changes in the world that have taken place since then. 


\section{References}

Bader, Lawrence N. 2004. "Pension Deficits: An Unnecessary Evil." Financial Analysts Journal 60(3): 15-21.

Bader, Lawrence N., and Jeremy Gold. 2003. "Reinventing Pension Actuarial Science." Pension Forum 14(2): 1-13.

Black, Fischer. 1980. "The Tax Consequences of Long-Run Pension Policy." Financial Analysts Journal 36(4): 21-28.

1989. "Should You Use Stocks to Hedge Your Pension Liability?" Financial Analysts Journal 45(1): 10-12.

Bodie, Zvi. 1990a. "Pension Funds and Financial Innovation." Financial Management 19(3): 11-22.

1990b. "The ABO, the PBO, and Pension Investment Policy." Financial Analysts Journal 46(5): 27-34.

2003. "On the Role of Bonds and Stocks in Corporate Pension Plans." Tijdschrift voor Corporate Finance 8(3): 63-69.

1996. "What the Pension Benefit Guaranty Corporation Can Learn from the Federal Savings and Loan Insurance Corporation." Journal of Financial Services Research 10(1): 83-100.

2005. "Less is Less: Straight Talk about Government Pension Insurance." Milken Institute Review (First Quarter): 38-45.

Bodie, Zvi, and Robert C. Merton. 1993. "Pension Benefit Guarantees in the United States: A Functional Analysis." In The Future of Pensions in the United States, edited by Ray Schmitt. Philadelphia: Pension Research Council of the Wharton School of the University of Pennsylvania.

Boyce, Steven, and Richard A. Ippolito. 2002. "The Cost of Pension Insurance." Journal of Risk and Insurance 69(2): 121-70.

Brown, Jeffrey R., and Mark J. Warshawsky. 2004. "Longevity-Insured Retirement Distributions from Pension Plans: Regulatory and Market Issues." In Public Policies and Private Pensions, edited by William G. Gale, John B. Shoven and Mark J. Warshawsky, Brookings.

Bulow, Jeremy I. 1982. “What Are Corporate Pension Liabilities?” Quarterly Journal of Economics 97(3): 435-52.

Center on Federal Financial Institutions. 2004. "PBGC: A Primer.” www.coffi. org/pubs/PBGC\%20A\%20Primer.pdf. Washington (April).

2005a. "PBGC: Policy Options." Washington (January). www.coffi. org/pubs/PBGC\%20Policy\%20Options\%20\%20January\%206\%202005.pdf.

2005b. "PBGC: Premium Hike Possibilities." Washington (April). www.coffi.org/pubs/PBGC\%20premium\%20hike\%20possibilities.pdf.

Choi, James J., David Laibson, and Brigitte C. Madrian. 2005. "\$100 Bills on the Sidewalk: Suboptimal Saving in 401(k) Plans.” Unpublished working paper. Harvard University. 
Congressional Budget Office. 2005a. "A Guide to Understanding the Pension Benefit Guaranty Corporation." Washington (September). www.cbo.gov/showdoc. $\mathrm{cfm}$ ?index $=6657 \&$ sequence $=0$.

2005b. "The Risk Exposure of the Pension Benefit Guaranty Corporation." Washington (September). www.cbo.gov/showdoc.cfm?index=6646\& sequence $=0$.

2005c. "Estimating the Costs of the Pension Benefit Guaranty Corporation." Washington (June 9). www.cbo.gov/showdoc.cfm?index $=6419 \&$ sequence $=0$.

2005d. "The Pension Benefit Guaranty Corporation: Financial Condition, Potential Risks, and Policy Options." Washington (June 15). www.cbo. gov/showdoc.cfm?index $=6426 \&$ sequence $=0$.

Coronado, Julia Lynn, and Nellie Liang. 2005. "The Influence of PBGC Insurance on Pension Fund Finances." Pension Research Council Working Paper 2005-10. Wharton School, University of Pennsylvania.

Coronado, Julia Lynn, and Steven A. Sharpe. 2003. "Did Pension Plan Accounting Contribute to a Stock Market Bubble?" BPEA, no. 1, 323-59.

Financial Accounting Standards Board. 2006. "Postretirement Benefit Obligations, Including Pensions: Project Summary." Project Update. Washington. www.fasb.org/project/postretirement_benefits.shtml.

Franzoni, Francesco, and José M. Marín. 2006. "Pension Plan Funding and Stock Market Efficiency." Journal of Finance 61(2): 921-56.

Gebhardtsbauer, Ron. 2003. "Strengthening Pension Security: Examining the Health and Future of Defined Benefit Pension Plans." Testimony before the Subcommittee on Employer-Employee Relations, U.S. House of Representatives, Washington (June 4).

General Accounting Office. 1987. "Pension Plans: Government Insurance Program Threatened by Its Growing Deficit." GAO/HRD-87-42. Report to the Chairman, Subcommittee on Oversight, Committee on Ways and Means, U.S. House of Representatives. Washington (March). archive.gao.gov/d2t4/ 132801.pdf.

1992. "Pension Plans: Hidden Liabilities Increase Claims against Government Insurance Program." GAO/HRD-93-7. Report to the Chairman, Employment and Housing Subcommittee, Committee on Government Operations, U.S. House of Representatives. Washington (December). archive.gao.gov/ d36t11/148206.pdf.

1994. "Underfunded Pension Plans: Stronger Funding Rules Needed to Reduce Federal Government's Growing Exposure." Testimony of Joseph F. Delfico before the Committee on Finance, U.S. Senate. GAO/T-HEHS-94-191 (June). archive.gao.gov/t2pbat3/151942.pdf.

1998. "Pension Benefit Guaranty Corporation: Financial Condition Improving, but Long-Term Risks Remain." GAO/HEHS-99-5. Report to the Chairman, Subcommittee on Employer-Employee Relations Committee on 
Education and the Workforce, U.S. House of Representatives. Washington (October). www.gao.gov/archive/1999/he99005.pdf.

2003a. "Pension Benefit Guaranty Corporation: Single-Employer Pension Insurance Program Faces Significant Long-Term Risks.” GAO-04-90. Report to Congressional Requesters. Washington (October). www.gao.gov/ new.items/d0490.pdf.

2003b. "Private Pensions: Changing Funding Rules and Enhancing Incentives Can Improve Plan Funding." GAO-04-176T. Testimony of Barbara D. Bovbjerg before the Committee on Education and the Workforce, U.S. House of Representatives. Washington (October). www.gao.gov/new.items/ d04176t.pdf.

. 2003c. "Pension Benefit Guaranty Corporation: Long-Term Financing Risks to Single-Employer Insurance Program Highlight Need for Comprehensive Reform." GAO-04-150T. Testimony of Barbara D. Bovbjerg before the Special Committee on Aging, U.S. Senate. Washington (October). www.gao. gov/new.items/d04150t.pdf.

2003d. "Private Pensions: Process Needed to Monitor the Mandated Interest Rate for Pension Calculations." GAO-03-313. www.gao.gov/new.items/ d03313.pdf

Gold, Jeremy. 2005. "Never Again.” Journal of Portfolio Management 32(1): 92-97.

Gold, Jeremy, and Nick Hudson. 2003. "Creating Value in Pension Plans (or, Gentlemen Prefer Bonds)." Journal of Applied Corporate Finance 15(4): 51-57.

Government Accountability Office. 2005. "Private Pensions: Recent Experiences of Large Defined Benefit Plans Illustrate Weaknesses in Funding Rules." GAO05-294. Report to Congressional Committees. Washington (May). www. gao.gov/new.items/d05294.pdf.

Groom, Theodore R., and John B. Shoven. 1999. "How the Pension System Should Be Reformed." Unpublished paper. Brookings (September). www.brookings. edu/es/events/erisa/99Papers/Erisa9.pdf.

Gustman, Alan L., and Thomas L. Steinmeier. 2004. "What People Don't Know about Their Pensions and Social Security." In Private Pensions and Public Policies, edited by William G. Gale, John B. Shoven, and Mark J. Warshawsky. Brookings.

Halperin, Daniel I., and Alicia H. Munnell. 1999. "How the Pension System Should Be Reformed." Unpublished paper. Brookings (September). www.brookings. edu/es/events/erisa/99Papers/Erisa10.pdf.

Hamilton, David T., Greg Gupton, and Alexandra Berhault. 2001. "Default and Recovery Rates of Corporate Bond Issuers." New York: Moody's Investors Service.

Ippolito, Richard A. 1987. "Pension Security: Has ERISA Had Any Effect?" Regulation 2: 15-22. 
2004. "How to Reduce the Cost of Federal Pension Insurance." Policy Analysis 523. Washington: Cato Institute (August 24).

John Hancock Financial Services. 2002. "Eighth Defined Contribution Plan Survey: Insight into Participant Investment Knowledge \& Behavior." Boston.

Kandarian, Steven A. 2003. Statement before the Committee on Education and the Workforce, U.S. House of Representatives. Washington (September 4). www.pbgc.gov/media/news-archive/ExecutiveTestimony/tm1169.html.

Lewis, Christopher M., and George G. Pennacchi 1999. "Valuing Insurance for Defined-Benefit Pension Plans." In Advances in Futures and Options Research, vol. 10, edited by Phelim Boyle, George G. Pennacchi, and Peter Ritchken. Amsterdam: Elsevier Science.

Lucas, Deborah, and Stephen P. Zeldes. 2006. "Valuing and Hedging Defined Benefit Pension Obligations-The Role of Stocks Revisited." Unpublished paper. Northwestern University and National Bureau of Economic Research.

McGill, Dan M., and others. 2005. Fundamentals of Private Pensions, 8th ed. Oxford University Press.

Mitchell, Olivia S. 1988. "Worker Knowledge of Pension Provisions." Journal of Labor Economics 6(1): 21-39.

Munnell, Alicia H. 1982. "Guaranteeing Private Pension Benefits: A Potentially Expensive Business." New England Economic Review (March/April): 24-47.

Oliver, Marilyn M., and Gregory S. Schlappich. 2000. "PBGC Plan Termination Cost Study." Washington: American Academy of Actuaries-Conference of Consulting Actuaries. www.actuary.org/pdf/pension/termstudyfinal.pdf.

Pennacchi, George. 2006. "Deposit Insurance, Bank Regulation and Financial System Risks." Journal of Monetary Economics 53(1): 1-30.

Pennacchi, George G., and Christopher M. Lewis. 1994. "The Value of Pension Benefit Guaranty Corporation Insurance." Journal of Money, Credit, and Banking 26(3, part 2): 735-53.

Pension Benefit Guaranty Corporation. 2000. "PBGC's Guarantee Limits: An Analysis of Benefits Received by Participants in Selected PBGC-Trusteed Plans." In Pension Insurance Data Book 1999. Washington. www.pbgc.gov/ docs/1999databook.pdf.

2005a. "PBGC Releases Fiscal Year 2005 Financial Results." News release. Washington (November). www.pbgc.gov/media/news-archive/2005/ pr06-06.html.

2005b. "Valuation of Benefits; Mortality Assumptions." 29 CFR Part 4044. Washington. www.pbgc.gov/docs/vbma.pdf.

2005c. 2004 Annual Report. Washington. www.pbgc.gov/docs/ 2004_annual_report.pdf.

2005d. "An Analysis of Frozen Defined Benefit Plans." Washington (December). www.pbgc.gov/docs/frozen_plans_1205.pdf. 
2005e. "PBGC Announces Maximum Insurance Benefit for 2006."

News release. Washington (December 12). www.pbgc.gov/media/news-archive/ 2005/pr06-09.html.

2005f. "Performance and Accountability Report, Fiscal Year 2005." Washington (November). www.pbgc.gov/docs/2005par.pdf.

2005g. "Testimony of Bradley D. Belt before the Committee on Budget, United States Senate.” News release. Washington (June 15). www.pbgc.gov/ media/news-archive/ExecutiveTestimony/tm13070.html.

2005h. Pension Insurance Data Book 2004. Washington. www.pbgc. gov/docs/2004databook.pdf.

Pension Committee of the Actuarial Standards Board. 1996. "Selection of Economic Assumptions for Measuring Pension Obligations." Actuarial Standard of Practice 27. Washington (December).

Perun, Pamela, and C. Eugene Steuerle. 2000. "ERISA at 50: A New Model for the Private Pension System.” Retirement Project Occasional Paper 4. Washington: Urban Institute (March). www.urban.org/toolkit/policybriefs/subjectbriefs.cfm? documenttypeid $=407$.

2003. "Reality Testing for Pension Reform." Washington: Urban Institute. www.urban.org/url.cfm?ID=410797.

Pesando, James E. 1982. "Investment Risk, Bankruptcy Risk, and Pension Reform in Canada." Journal of Finance 37(3): 741-49.

1996. "The Government's Role in Insuring Pensions." In Securing Employer-Based Pensions: An International Perspective, edited by Zvi Bodie, Olivia S. Mitchell, and John A. Turner. Philadelphia: Pension Research Council and University of Pennsylvania Press.

Ruthen, Seth. 2005. 'Defined Benefit Pension Plans' Interest Rate Exposure at Record High." PIMCO Bonds Publication (February). www.pimco.com/LeftNav/ Viewpoints/2005/Pension+Plan+Rate+Exposure+Feb05.htm.

Salisbury, Dallas L. 1996 “Comments” (on James E. Pesando's “The Government's Role in Insuring Pensions"). In Securing Employer-Based Pensions: An International Perspective, edited by Zvi Bodie, Olivia S. Mitchell, and John A. Turner. Philadelphia: Pension Research Council and University of Pennsylvania Press.

Sharpe, William F. 1976. "Corporate Pension Funding Policy." Journal of Financial Economics 3(3): 183-93.

Smalhout, James H. 1993. "Avoiding the Next Guaranteed Bailout: Reforms for the Pension Insurance Program.” Brookings Review 11(2): 12-15.

Starr-McCluer, Martha, and Annika Sundén. 1999. "Workers' Knowledge of Their Pension Coverage: A Reevaluation." In The Creation and Analysis of EmployerEmployee Matched Data, edited by John C. Haltiwanger and others. Contributions to Economic Analysis Series 241. Amsterdam: Elsevier Science.

Stiglitz, Joseph E. 1993. "Perspectives on the Role of Government Risk-Bearing within the Financial Sector." In Government Risk-Bearing, edited by Mark S. Sniderman. Boston: Kluwer Academic Publishers. 
Taylor, Andrew. 1993. "Pension Woes Raise Specter of Thrift-Style Bailout." Congressional Quarterly Weekly (February 13): 307-08.

U.S. Congress Joint Committee on Taxation. 2005. "Present Law and Background Relating to Employer-Sponsored Defined Benefit Pension Plans and the Pension Benefit Guaranty Corporation ('PBGC')." Washington (March 7). www.house.gov/jct/x-9-05.pdf.

U.S. Department of Labor, Employee Benefits Security Administration. 2006. "Private Pension Plan Bulletin: Abstract of 2001 Form 5500 Annual Reports." Washington. www.dol.gov/ebsa/PDF/2001pensionplanbulletin.PDF.

U.S. House of Representatives Committee on Ways and Means. 2004. 2004 Greenbook: Background Material and Data on the Programs within the Jurisdiction of the Committee on Ways and Means. WMPC 108-6. Washington. waysandmeans.house.gov/media/pdf/greenbook2003/Section14.pdf.

VanDerhei, Jack L. 1990. “An Empirical Analysis of Risk-Related Insurance Premiums for the PBGC." Journal of Risk and Insurance 57(2): 240-59.

Warshawsky, Mark J., Neal McCall, and John D. Worth. 2005. "Regulating Single Employer Defined Benefit Pension Plans: A Modern Approach." Pension Research Council Working Paper 2005-12. Philadelphia: Pension Research Council of the Wharton School of the University of Pennsylvania. rider.wharton. upenn.edu/ prc/PRC/WP/Warshawsky\%20et\%20al\%20WP12.pdf.

Watson Wyatt Worldwide. 2005. "Recent Funding and Sponsorship Trends among the Fortune 1000." Insider (June). www.watsonwyatt.com/us/pubs/insider/ showarticle.asp?ArticleID $=14750$.

Weaver, Carolyn L. 1997. "Government Guarantees of Private Pension Benefits: Current Problems and Market-Based Solutions." In Public Policy Toward Pensions, edited by Sylvester J. Schieber and John B. Shoven. MIT Press. 